\title{
CUSTOS BANCÁRIOS DE TRANSAÇÃO DO CRÉDITO RURAL NO BRASIL
}

\author{
ANDRÉ SOUTO MAIOR PESSÔA \\ Engenheiro Agrônomo
}

Orientador: Prof. Dr. Paulo Fernando Cidade de Araújo

Dissertação apresentada à Escola Superior de Agricultura "Luiz de Queiroz", da Universidade de São Paulo, para a obtenção do título de Mestre em Agronomia, Área de Concentração: Economia Agrária.

P I R A C I C A B A

Estado de São Paulo - Brasil

Abril - 1996 
Dados Internacionais de Catalogação na Publicação (CIP)

DIVISĀO DE BIBLIOTECA E DOCUMENTAÇĀO - Campus "Luiz de Queiroz"/USP

Pessôa, André Souto Maior

Custos bancários de transação do crédito rural no Brasil / André Souto

Maior Pessôa. - - Piracicaba, 1996.

94p. : il.

Dissertação (mestrado) - Escola Superior de Agricultura Luiz de Queiroz, 1996.

Bibliografia.

1. Credito agricola - Custo bancário - Brasil 2. Financiamento agricola - Brasil I. Título

CDD 332.71 


\section{CUSTOS BANCÁRIOS DE TRANSAÇÃO DO CRÉDITO RURAL NO BRASIL}

ANDRÉ SOUTO MAIOR PESSÔA

Aprovada em: 12.04.1996

Comissão julgadora:

Prof. Dr. Paulo Fernando Cidade de Araújo ESALQ/USP

Prof. Dr. Ricardo Shirota ESALQ/USP

Prof. Dr. José Roberto Mendonça de Barros FEA/USP

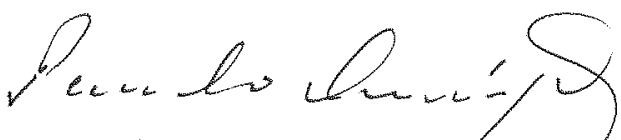

Prof. Dr. Paulo Fernando Cidade de Araújo

Orientador 
Dedico aos meus pais, Múcio e Maria Helena 


\section{A GRADE C I M N T OS}

A realização desse trabalho não seria possivel sem a colaboração decisiva de muitos amigos e colegas. Portanto agradeço a todos aqueles que ao longo desses anos me emprestaram seu apoio, estímulo, conhecimento, paciência, carinho e amizade.

Agradeço ao Departamento de Economia e Sociologia Rural pela oportunidade de realizar o curso de mestrado e ao CNPq pela bolsa de estudos que permitiu minha manutenção em Piracicaba.

Aos colegas Jan Astron, Leila Campos Vieira, Paulo Nuevo, Weimar da Rocha Filho, José Valdemir Müchem, Peri Shikida, Pedro Henrique Z. da Conceição, Eva Chabalin, Alivínio de Almeida, Maria de Fátima Del Guidice, Mirian Rumenos Piedade Bacchi, Sigismundo Bialokorski e Alfredo Picerno agradeço pela amizade e convivência fraterna que compartilhamos em todos os momentos.

Aos professores Evaristo Marzabal Neves, Guilherme Leite da Silva Dias, Geraldo Sant'Ana de Camargo Barros, Ricardo Shirota, Carlos José Caetano Bacha, José Vicente Caixeta Filho, Heloísa Lee Burnquinst, Rodolfo Hoffmann e Joaquim José Guilhoto, minha gratidão pelos ensinamentos técnicos e humanos transmitidos ao longo do curso.

Aos funcionários do Departamento de Economia e Sociologia Rural agradeço pela presteza e simpatia com que sempre se dispuseram a me ajudar no dia a dia. Em 
especial, agradeço às secretárias Márcia Previtalli, Maieli e Elenice, e às bibliotecárias Luciane e Angélica.

Agradeço ainda a todos os amigos e colegas da MB Associados pelo estímulo e confiança que sempre me dedicaram. Em especial, agradeço à querida Maria Cristina Mendonça de Barros pelas vezes em que assumiu o papel de mãe e me empurrou para frente. Aos amigos Celso de Campos Toledo Neto e Paulo de Tarso Nobre da Cunha sou eternamente grato pelas tantas horas dedicadas ao aperfeiçoamento deste trabalho.

Rendo também minha gratidão a todos os amigos e parentes, que ao longo desses anos serviram de fonte de apoio e incentivo para que eu seguisse em frente e concluísse este trabalho. Entre eles estão: André e Maria Carolina Lahóz Mendonça de Barros, Marco Antônio e Flávia Machado, Alan Coelho, Luís Roberto e Andréia Moreira Lima Leite, Eduardo e Flávia Barker, Luis Antônio Dias Paes, Suleiman Hassuani, Marcelo Cardoso Mendonça de Barros, Norberto Giangrande Júnior, Devancir Aparecido Romão, Fernando Montero, Tereza Maria Fernandez Dias da Silva, Fátima Cardoso, Hiyam Chafic Halabi, meus tios Paulo e Marilda, minha tia Arlete e meus primos Paula, Guilherme, Carolina e Frederico.

Ao meu orientador e grande amigo Prof. Paulo Cidade presto minha eterna gratidão, pois sem o seu conhecimento e sem sua incomparável dedicação este trabalho não seria concretizado. Acima de tudo, agradeço pela oportunidade de poder usufruir de sua vasta experiência de vida, de sua grande visão de futuro, de sua permanente honestidade de propósitos e de sua amizade sincera. Quem teve o privilégio de ser seu 
aluno, descobriu o prazer de estudar, a força do saber, a vontade de agir e a responsabilidade de vencer, virtudes que apenas os sábios conseguem transmitir.

Também dedico um agradecimento especial aos meus novos irmãos, Alexandre Lahóz Mendonça de Barros e Guilherme Soria Bastos Filho, amigos de todas as horas, possuidores de inteligência e nobreza de caráter incomuns. Mais que grandes colegas, eles constituem um porto seguro para toda a minha vida.

Aos meus pais paulistas, José Roberto e Ruth Mendonça de Barros expresso a minha eterna gratidão. Ao me adotarem, amavelmente, como seu filho nordestino e me estimularem sempre a seguir o bom caminho, eles contribuíram decisivamente em todos os êxitos que obtive em São Paulo.

Agradeço de todo coração aos meus pais, Múcio e Maria Helena, e aos meus irmãos Alexandre, Maurício e Isabella. O estímulo, a confiança e o amor permanentemente transmitidos ao longo de todos esses anos de distância e saudade foram sempre um fator decisivo em minha caminhada.

Por fim, expresso meu agradecimento todo especial a minha amada Salma. Ela é a fonte de toda a minha fé num futuro feliz, em razão de todo amor, companheirismo e paciência a mim dedicados durante esse trabalho. 


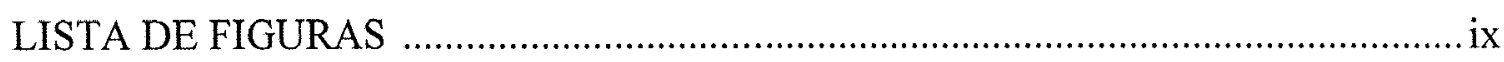

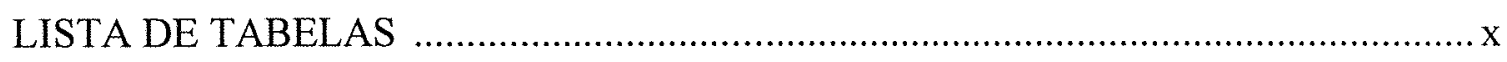

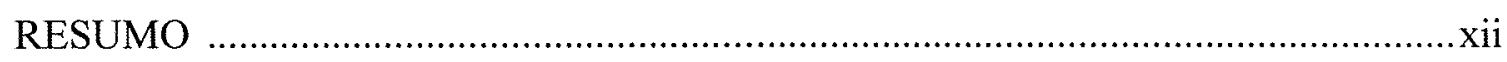

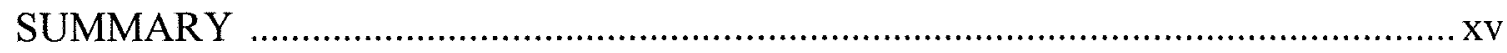

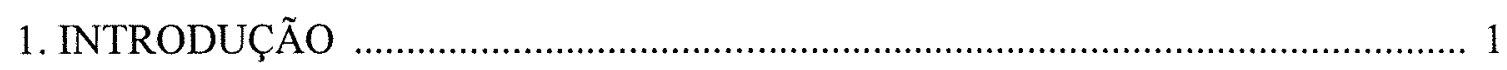

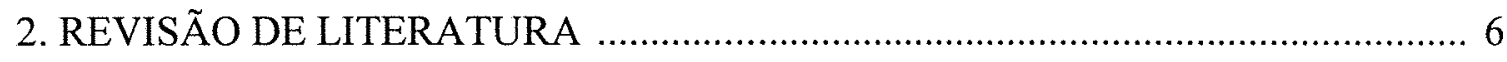

2.1. Sistema financeiro e desenvolvimento econômico ....................................... 6

2.2. Sistema financeiro e estabilização no Brasil .............................................. 15

2.3. Financiamento rural no Brasil ............................................................... 19

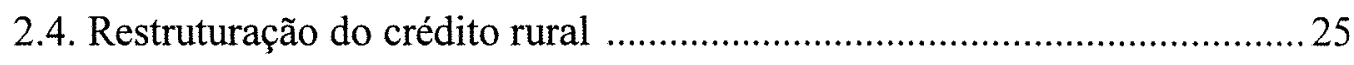

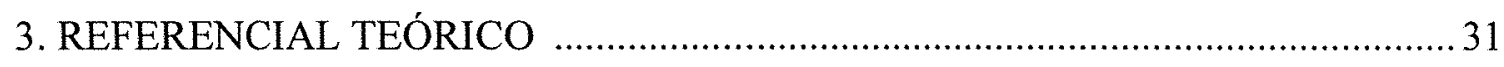

3.1. Custos bancários de transação no crédito rural ........................................... 31

3.2. Custos de transação e racionamento no crédito rural ..................................38

3.3. Estimativas anteriores ......................................................................... 41

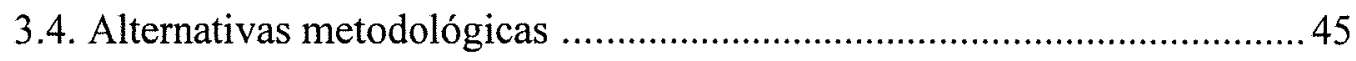

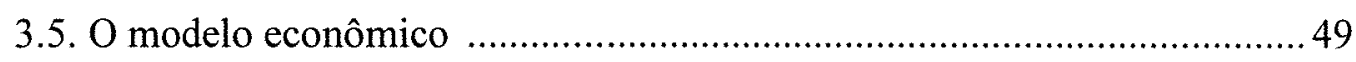

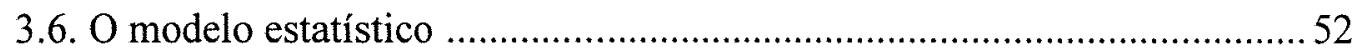


3.7. Dados e definição das variáveis .54

4. ANÁLISE DOS RESULTADOS 57

4.1. Análise qualitativa 57

4.2. Análise econométrica 67

4.3. Teste de estabilidade do modelo .71

5. CONCLUSÕES .74

6. REFERÊNCIAS BIBLIOGRÁFICAS 81

7. APÊNDICE 1 87

8. APÊNDICE 2 89

9. APÊNDICE 3 91

10. APÊNDICE 4 92 


\section{LISTA DE FIGURAS}

Página

FIGURA 1 Indicadores da expansão da atividade financeira, 1965-1987 _.................... 8

FIGURA 2 Evolução do crédito rural no Brasil, 1970-1994 ……................................21

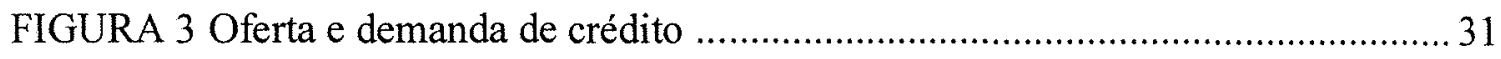


LISTA DE TABELAS

Página

TABELA 1. Poupança, investimento e crescimento em países em desenvolvimento, 1965-1987 7

TABELA 2. Taxas de crescimento e outros indicadores econômicos em grupos de países com taxas de juros reais positivas, moderadamente negativas e muito negativas, 1974-1985 12

TABELA 3. Custo de transação por unidade monetária de empréstimo ..................58

TABELA 4. Custo de transação por contrato de crédito rural ................................60

TABELA 5. Medidas de tamanho da carteira de crédito rural ................................61

TABELA 6. Eficácia no uso da tecnologia bancária disponível..........................61

TABELA 7. Custos de produção de algumas lavouras selecionadas, 1995 .............62

TABELA 8. Área de plantio por lavoura com o valor médio dos contratos, $1995 \ldots 63$

TABELA 9. Relação entre aplicações em crédito rural e aplicações totais da agência

TABELA 10. Gastos com pessoal ocupado em crédito rural .................................64

TABELA 11. Fatores de eficiência no custo de transação nos 4 bancos estudados ...65

TABELA 12. Coeficientes de regressão e estatísticas do modelo 1a para estimar as relações entre custo bancário de transação por unidade monetária de empréstimo $\left(Y_{l}\right)$ e fatores determinantes 
TABELA 13. Coeficientes de regressão e estatísticas do modelo $\mathbf{2 b}$ para estimar as relações entre custo bancário de transação por contrato $\left(Y_{2}\right)$ e fatores determinantes

TABELA 14. Probabilidades associadas ao Teste de Chow 73 


\title{
CUSTOS BANCÁRIOS DE TRANSAÇÃO DO CRÉDITO RURAL
} NO BRASIL

\author{
Autor: André Souto Maior Pessôa \\ Orientador: Prof. Dr. Paulo Fernando Cidade de Araújo
}

\section{RESUMO}

O sistema financeiro tem entre suas atividades principais a transferência de poupança de agentes econômicos superavitários para agentes deficitários proporcionando aumento na taxa de investimento das economias. No Brasil a crise fiscal do início da década de 80 provocou um distanciamento do sistema financeiro do financiamento das atividades produtivas, em particular da agricultura, que tem prazo longo de recuperação de capital para um ambiente de inflação elevada. $O$ financiamento da dívida pública passou a ser a principal atividade dos bancos no Brasil. A zeragem automática junto à mesa do Banco Central garantia rentabilidade e segurança nessa atividade. Os ganhos 
com a inflação através do float $^{1}$, decorrente da elevada inflação permitiu ganhos expressivos e uma expansão sem precedentes do sistema financeiro.

Com o processo de estabilização da economia (controle da inflação e ajuste fiscal), o sistema financeiro está perdendo aos poucos esse nicho e deve buscar novas oportunidades de atuação junto às atividades produtivas, entre as quais a agricultura. É necessário, então, que os bancos estejam preparados para operar com custos de transação compatíveis com uma economia estável.

Os custos bancários de transação no crédito rural no Brasil serão certamente um obstáculo à restruturação do modelo de financiamento rural, já que atualmente encontram-se negativamente influenciados pelo longo período de desajuste macroeconômico. Para tentar avaliar o estado da arte em que se encontram os custos bancários de transação no crédito rural em bancos oficiais brasileiros, essa pesquisa analisou um conjunto de 62 agências de 4 bancos que operam em 3 macroregiões.

As agências foram analisadas relacionando-se os custos de transação (medidos por unidade monetária de empréstimo e por contrato) com alguns de seus fatores determinantes, tais como: tamanho da carteira de crédito rural (medido pelo volume total aplicado em crédito rural e pelo número de contratos); grau de especialização da agência ( medido pela relação entre as aplicações em crédito rural e aplicações totais da agência);

\footnotetext{
${ }^{1}$ Float - é definido aqui como o tempo decorrido entre a captação de recursos pelos intermediários financeiros (taxas, impostos, depósitos à vista) e o repasse desses recursos aos seus credores finais. Num ambiente de inflação elevada a aplicação desses recursos no over-night permitiu aos bancos lucros expressivos.
} 
eficácia no uso da tecnologia bancária disponível (medida pelo valor médio dos contratos de crédito rural) e pelo fator tempo.

Tanto a avaliação qualitativa quanto a análise estatística dos resultados demonstram que os custos de transação são extremamente elevados. Os fatores relacionados à escala de operações da agência (tamanho da carteira e valor médio dos contratos) são os que apresentam melhores oportunidades de redução dos custos de transação. Ou seja, aumentando-se a escala de operações em crédito rural é possível reduzir substancialmente os custo de transação em nível de agência.

Já o grau de especialização da agência não se mostrou significativo, revelando uma pequena influência sobre os custos de transação. Pôde-se constatar através da variável dummy que os custos de transação sofreram uma redução estrutural entre 1990 e 1993, certamente decorrente do aperfeiçoamento da tecnologia bancária nesse período.

Finalmente pode-se concluir que um acompanhamento permanente e detalhado dos custos bancários de transação no crédito rural nos bancos brasileiros será condição necessária para garantir a eficiência microeconômica para o modelo de financiamento rural que a estabilização de nossa economia irá exigir do sistema financeiro nacional. 


\title{
RURAL CREDIT TRANSACTION COSTS FOR BANKS IN BRAZIL
}

\author{
Author: André Souto Maior Pessôa \\ Adviser: Prof. Dr. Paulo Fernando Cidade de Araújo
}

\section{SUMMARY}

One of the main activities of the financial system is the transfer of savings from economic agents in surplus of financial resources to those in deficits, promoting an increase of the savings and investment rates of the economy.

In Brazil, the fiscal crisis of the 80's induced a " crowding-out" effect, especially against agriculture which has a long maturity for a highly inflationary environment.

As a consequence, the banking system's main activity has been concentrated in servicing the public debt operations, using instruments such as the so-called 'automatic clearing' guaranteed profitability and security for those operations. The inflationary gains allowed an expansion of the financial system with no precedents in history.

With the recent macroeconomic stabilization policy, through inflation control and fiscal adjustment, the financial system is losing this niche and must search for new 
opportunities in the private sectors, including agriculture. Thus, it is necessary that the banks are prepared to operate with compatible transaction costs, typical of a stable environment.

The high transaction costs of the rural credit in Brazil will be an obstacle to the reestructuration of the agricultural credit system. It is evident that the long period of macroeconomic problems contributed to exacerbate those misalignments.

This research is an attempt to evaluate the level of the transaction costs in rural credit provided by the Brazilian official banks. The empirical work is based on a sample of 62 branches of 4 banks operating in 3 'macro-regions' of the country.

The agencies were evaluated by an econometric model that estimated the economic relationships between the transaction cost (measured by two different concepts) and several explanatory factors, such as: (i) size of the rural credit portfolio; (ii) degree of specialization of the branch; (iii) efficiency in the use of the banking tecnology; and, (iv) time.

Both the qualitative and the statistical analysis show that the transaction costs seems to be extremely high. Those factors related to the scale of operations are the ones that have greater explanatory power and the primary targets for a cost reduction policy. In other words, it is possible to decrease the costs of transaction by increasing the scale of operations.

The degree of specialization of the branch does not seem to affect significantly the transaction costs. On the other hand, the dummy variable included in the model to 
capture the effect of the banking technology shows a structural reduction in the transaction costs between 1990 and 1993.

Finally, given the new demands resulting from the stabilization process, it is possible to conclude that the keen monitoring of the banks' costs will be a 'sine-quanon' condition to guarantee the microeconomic efficiency in the process of providing financial services to agriculture. 


\section{1 - INTRODUÇÃO}

Estabilização econômica e reformas estruturais. Esses temas têm monopolizado os debates nos últimos anos. Muitos economistas, cientistas sociais e políticos, dos mais diversos matizes ideológicos, têm insistido que a estabilização de nossa economia só ocorrerá após estarem concluídas uma série de reformas estruturais no País.

O ponto central dessa discussão é a redefinição do papel do Estado. As reformas do regime fiscal, da ordem política, do sistema previdenciário, do poder judiciário e do sistema financeiro apontam que o Estado brasileiro está desenhado para um modelo de desenvolvimento que não norteia mais o cotidiano dos agentes econômicos. A restruturação do Estado e a definição de novos parâmetros de inserção deste na economia parece ser um dos maiores desafios para os formuladores de política econômica nos próximos anos.

Para o complexo agroindustrial brasileiro, responsável hoje por mais de $30 \%$ do Produto Interno Bruto (PIB), duas das reformas estruturais mais importantes são a fiscal e a do sistema financeiro. O setor moderno da agricultura brasileira convive com estruturas antigas, herdadas do modelo de desenvolvimento adotado pelo Pais até os anos 80. Neste contexto, merecem destaque a excessiva carga de tributos indiretos que 
recaem sobre o setor e um modelo de financiamento rural altamente dependente do intervenção do Tesouro Nacional, enfrentando problemas como a elevada concentração das aplicações, a insuficiência de recursos e a alta taxa de inadimplência, conforme apontam ALMEIDA (1995) e ARAÚJO (1996).

A questão da tributação da agricultura deverá estar presente na reforma fiscal. Nas propostas apresentadas para tal reforma, observa-se uma tendência de privilegiar a tributação direta em detrimento da tributação indireta. A redução da tributação indireta atenuará também as distorções de preços relativos. Por exemplo, desonerando as exportações agrícolas de produtos básicos e semi-elaborados, já que as exportações de produtos manufaturados não sofrem a mesma tributação. A cobrança de impostos diretos na agricultura brasileira é irrisória, chegando ao ponto do governo suspender a cobrança do Imposto Territorial Rural (ITR) por dois anos, pois a receita prevista não cobriria nem mesmo os custos com a cobrança desse tributo.

Já a reforma do sistema de crédito rural se enquadra no contexto de uma ampla revisão de todo o sistema financeiro no Brasil. A institucionalização de um banco central independente, que tenha como principal atribuição a proteção da moeda nacional, através de uma política monetária austera, mesmo não sendo uma questão consensual, ganha força exatamente pela possibilidade de poder contribuir para um menor grau de liberdade do Tesouro Nacional na oferta de crédito rural a taxas subsidiadas, ajudando a controlar a expansão da base monetária e o desequilíbrio fiscal. 
Do ponto de vista operacional, um novo arranjo entre os setores financeiros público e privado deve ocorrer no que se refere à oferta de crédito em geral, e no crédito rural em particular. Essas mudanças devem objetivar a maior participação do setor privado financeiro na alocação de crédito para financiar os investimentos produtivos.

Ao setor público caberá um papel de regulamentação e cooperação nas atividades que venham a ser desempenhadas pelo setor privado. Dada a heterogeneidade que caracteriza a agricultura brasileira inter e intraregionalmente, ao Estado caberá ainda um papel de financiador e gestor de diversas ações no sentido de promover condições de desenvolvimento naquelas regiões e/ou grupos de produtores que por, falhas de mercado, não venham a ser atendidos pelo setor privado. Outra função importante que caberá ao setor público e à operacionalização de instrumentos para intervir em situações de emergência, como por exemplo em calamidades climáticas como sêcas ou enchentes.

A relativa ausência do setor privado no financiamento rural no Brasil tem explicações de duas naturezas, uma geral e outra especifica. De uma forma mais geral, todo o sistema produtivo sofreu um racionamento nas fontes privadas de crédito, uma vez que para o mercado financeiro não houve, nos últimos anos, uma alternativa tão atraente, em termos de rentabilidade e segurança, quanto o financiamento da dívida do setor público.

De uma forma mais específica, a agricultura sofreu uma restrição de crédito privado por se caracterizar como uma atividade que envolve muitos riscos. O primeiro e mais evidente é o risco climático. O segundo é o risco de renda, associado à 
inelasticidade da oferta dos produtos agrícolas, que está diretamente relacionada com a sazonalidade da produção. Some-se o risco de crédito inerente a uma atividade de baixa rentabilidade e com prazos demasiadamente longos de recuperação de capital, particularmente em um ambiente de inflação alta.

As tentativas de atenuar esses riscos para os financiadores da atividade agrícola mostraram-se extremamente desastrosas nos últimos anos. O PROAGRO (seguro agrícola) objeto de inúmeras fraudes, não foi honrado pelo Tesouro Nacional em muitas ocasiões, tendo-se inclusive recorrido recentemente a securitizações das dívidas junto ao sistema financeiro.

O Programa de Garantia de Preços Mínimos (PGPM) também perdeu sua funcionalidade na medida em que o governo perdeu a capacidade de cumprir as regras e promoveu sucessivas prorrogações dos vencimentos. E por fim, a inflação alta, que levou a repetidas experiências de controle de preços agrícolas e à prática de taxas de juros elevadíssimas, determinou uma forte inadimplência no setor, tornando o risco de crédito quase proibitivo para o financiamento da agricultura.

Vale salientar que num cenário de estabilização macroeconômica, o financiamento da dívida pública se dará em patamares menores de taxas de juros e os riscos da atividade agrícola tendem a ser atenuados, pelo uso de instrumentos mais confiáveis, tais como os mercados futuros e de derivativos.

A reestruturação do sitema financeiro no Brasil deve evidenciar o fato de que o financiamento rural constitui um novo nicho de atuação dos bancos num cenário de 
estabilização da economia, já que o agribusiness representa uma parcela importante do PIB no Brasil. Os bancos brasileiros não têm tradição em operar, em larga escala, linhas de crédito para a agricultura; sendo assim, será necessário implantar carteiras agrícolas que operem com eficiência.

Como se sabe, o custo de transação nas operações de crédito rural é um bom indicativo da eficiência do agente financiador. Conhecer melhor as variáveis que influenciam esse custo certamente é um importante parâmetro na tomada de decisão dos intermediários financeiros visando a definição de uma nova logística de financiamento à agricultura brasileira.

Este trabalho objetiva fazer uma análise dos custos de transação bancária no financiamento agrícola no Brasil, contribuindo para a formulação de estratégias que melhorem o desempenho dos bancos nos serviços de crédito prestados aos agricultores. Para tanto será analisada a evolução recente do sistema financeiro rural e serão estimados e analisados os custos bancários dos empréstimos rurais em 62 agências de 4 bancos oficiais que integram o Sistema Nacional de Crédito Rural (SNCR) criado pela Lei 4829 de novembro de 1965. 


\section{2 - REVISÃO DE LITERATURA}

\section{1 - Sistema financeiro e desenvolvimento econômico}

A alocação eficiente de recursos escassos para fins alternativos é o objetivo essencial da ciência econômica. Numa economia moderna, alocar eficientemente a poupança das empresas e dos indivíduos para oportunidades de investimentos lucrativos é da maior importância para o crescimento. Esta é a atividade básica em torno da qual se organiza o sistema financeiro.

O desenvolvimento econômico está intimamente relacionado com o processo de acumulação de capital e sua distribuição entre os agentes econômicos. $\mathrm{O}$ acúmulo de capital permite que ocorra um aumento na produtividade da economia, o que por sua vez leva a um aumento na taxa de poupança social, induzindo a uma elevação na taxa de investimento que garantirá o aumento no processo de acumulação.

GURLEY \& SHAW (1960) definiram o sistema financeiro como um agente catalisador do fluxo de poupança nas modernas economias industriais. Ao transferir o excedente de poupança de agentes econômicos superavitários para agentes deficitários, o sistema financeiro possibilita a elevação da taxa de investimento. Portanto, dois 
processos estão diretamente relacionados com a dinâmica do desenvolvimento econômico: crescimento da taxa de poupança e sua eficiente alocação para investimentos.

A eficiência na alocação das poupanças interna e externa tem sido o fator determinante do sucesso das nações no processo de crescimento de sua capacidade produtiva e, logo, de sua renda. Os países em desenvolvimento cujo crescimento foi mais rápido apresentaram índices de poupança e investimento mais elevados que os países de crescimento lento. A Tabela 1, a seguir, mostra a relação entre poupança, investimento e crescimento do PIB em 80 países em desenvolvimento.

Tabela 1 - Poupança, investimento e crescimento em países em desenvolvimento, 19651987.

\begin{tabular}{||c|c|c|c||}
\hline $\begin{array}{c}\text { Grupo de Países por Taxa de } \\
\text { Crescimento do PIB }\end{array}$ & $\begin{array}{c}\text { Poupança Nacional } \\
\text { Bruta / PIB }\end{array}$ & $\begin{array}{c}\text { Investimento } \\
\text { Bruto / PIB }\end{array}$ & M2 / PIB \\
\hline $\begin{array}{c}\text { Crescimento Alto (mais de 7\%) } \\
\text { Sete Países Inclusive China } \\
\text { Sete Países Exclusive China }\end{array}$ & $28,0 \%$ & $28,6 \%$ & $43,0 \%$ \\
\hline $\begin{array}{c}\text { Crescimento Médio (3 a 7\%) } \\
\text { 51 Países }\end{array}$ & $18,5 \%$ & $22,6 \%$ & \\
\hline $\begin{array}{c}\text { Crescimento Baixo } \\
\text { (menos de 3\%) } \\
\text { 22 Países }\end{array}$ & & & $31,2 \%$ \\
\hline
\end{tabular}

Fonte: International Financial Statistics (IFM) e World Bank.

${ }^{1}$ M2 é a moeda em circulação mais depósitos à vista, a prazo e de poupança nos bancos. O investimento é o investimento interno bruto.

Vários são os fatores que interferem no nível de poupança: renda per capita, crescimento da renda, composição etária da população, sistema de previdência social, 
quantidade e qualidade dos serviços públicos (sobretudo os sociais), carga tributária e déficit governamental. As expectativas quanto à estabilidade macroeconômica e as políticas públicas também exercem influência sobre a poupança.

Do coeficiente $\mathbf{M}_{2 / P I B}$ na Tabela 1, pode-se observar que os países de crescimento mais rápido têm também a maior expansão da atividade financeira quando comparados aos países de crescimento lento. À medida que o sistema financeiro capta mais poupança, maior é a expansão da atividade financeira. Em geral, os países de alta renda apresentam sistemas financeiros mais amplos que os países de baixa renda. Podese verificar esse fato pela relação entre $\boldsymbol{M 3}$ (passivos líquidos) e Produto Nacional Bruto (PNB) apresentada na Figura 1.

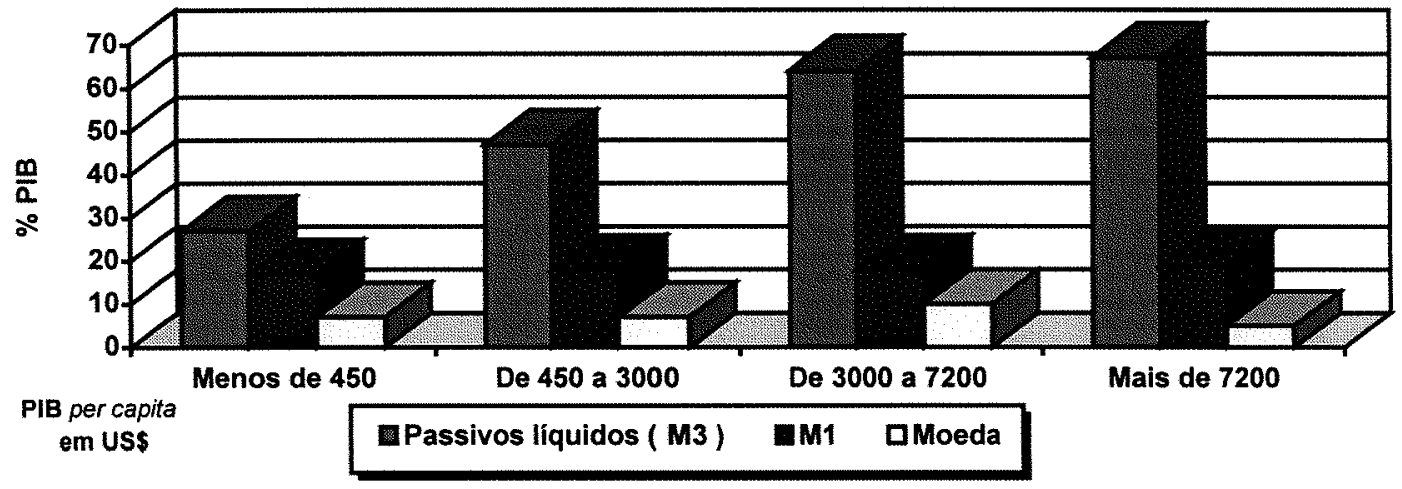

Fonte: World Bank

MI é a soma de moeda em poder do público e depósitos à vista. M3 (passivos líquidos) é a soma de MI mais depósitos a prazo fixo e outros depósitos em instituições financeiras.

Figura 1 - Participação do M1, M3 e moeda no PIB como indicadores da expansão da atividade financeira e em função do nível do PIB per capita em 80 países, $1965-1987$ 
$\mathrm{O}$ crescimento mais rápido, a maior quantidade de investimentos e a maior expansão da atividade financeira advêm em boa parte do crescimento da poupança social. No entanto, quanto maior for o desenvolvimento do sistema financeiro, maior será a quantidade de investimentos lucrativos financiados e maior poderá ser a taxa de crescimento econômico. Logo, há uma ligação entre crescimento econômico e desenvolvimento do sistema financeiro.

Durante as décadas de 50 e 60 os países em desenvolvimento contavam com sistemas financeiros rudimentares, que tinham como atividade básica o fornecimento de crédito para a atividade comercial externa e doméstica. Com o intuito de adequar os seus sistemas financeiros a uma alocação de recursos compatível com as estratégias desenvolvimentistas, os governos desses países promoveram profundas restruturações em toda a atividade financeira.

A criação de bancos de desenvolvimento com o objetivo de financiar, a taxas de juros baixas, os setores líderes do desenvolvimento, foi medida largamente utilizada. Todos os países da América Latina que aplicaram o Programa de Substituição de Importações da Comissão Econômica para a América Latina (CEPAL) adotaram essas medidas. Entre eles, Brasil, Chile, Argentina, Colômbia e México, conforme ilustra o estudo da FUNDAP (1991). Também, em vários países em desenvolvimento, as instituições financeiras já existentes foram estimuladas/forçadas a agir desta forma.

Um exemplo dessa estratégia foi a abertura de sucursais rurais para captar depósitos e conceder crédito barato a agricultores, mesmo em regiões onde a 
pulverização de um sem número de pequenas unidades produtivas, o baixo valor médio dos contratos e as garantias insuficientes destes tomadores, apresentavam-se como indicadores proibitivos dessas operações, sob quaisquer aspectos de eficiência microeconômica. É evidente que o objetivo desses progamas não era a busca de eficiência microeconômica na alocação de recursos, mas sim prover o acesso desses produtores ao crédito que dificilmente teriam através do mercado financeiro privado.

Freqüentemente, o sistema financeiro também atuou como um agente de financiamento dos próprios governos, que, para financiar seus crescentes déficits orçamentários e empresas estatais, transformaram-se em grandes tomadores de empréstimos. Num primeiro momento essa estratégia funcionou e muitos países apresentaram altas taxas de crescimento durante a década de 60 e até meados dos anos 70. A partir daí, ficou claro que a excessiva regulamentação da atividade financeira e o controle estatal das taxas de juros impediam o desenvolvimento do sistema.

Esse processo trouxe no médio prazo uma ineficiência sistêmica que, em última instância, impossibilitava a continuidade do crescimento sustentado num prazo mais longo. Tendo como pano de fundo essas observações, McKINNON (1973) desenvolveu a teoria da repressão financeira. A ação do Estado no sentido de garantir taxas de juros baixas, para incentivar o investimento produtivo, acabou por gerar um excesso de demanda no mercado de crédito, com um conseqüente racionamento, que levou a um grande número de efeitos negativos. 
Alguns desses efeitos são apontados em um estudo da FUNDAP (1991). Os principais são: i) concentração do crédito em empresas que pudessem oferecer maiores garantias, prejudicando a eficiência alocativa; ii) seleção de projetos com baixas taxas de retorno, implicando desestímulo à produtividade e eficiência; iii) aumento na procura de ativos reais, reduzindo a poupança em favor do consumo; iv) estímulo ao autofinanciamento e aos mercados informais fragmentados, com taxas de juros maiores, reduzindo em última instância o tamanho do sistema financeiro formal.

A subordinação do sistema financeiro às necessidades dos modelos econômicos adotados pelos países em desenvolvimento e a repressão financeira trouxeram duas graves distorções para a atividade financeira. Em primeiro lugar, a atividade de financiamento de curto prazo da dívida pública foi se transformando na principal atividade do sistema financeiro privado nesses países, em detrimento do financiamento de longo prazo de atividades produtivas. Em segundo lugar, os governos desses países viram-se obrigados a aumentar cada vez mais sua tutela sobre o setor, via regulamentação das atividades financeiras ou através do controle das taxas de juros, em geral subsidiadas, praticadas no mercado doméstico.

Para resolver a primeira distorção é imperioso o ajuste macroeconômico, que passa pela obtenção de um rigoroso equilíbrio fiscal, pelo controle do processo inflacionário e pela consolidação de um saldo favorável na conta de transações correntes. Já a solução para a segunda distorção está relacionada com um processo de reestruturação do setor. Esse processo passa em boa medida por modificações 
institucionais, como a liberalização dos fluxos internacionais de capitais e crédito, permitindo a harmonização das taxas de juros face a um equilíbrio entre oferta e demanda de poupança.

Desta forma, o nível de investimento cresceria, o estoque de ativos financeiros aumentaria relativamente ao produto da economia, gerando o aprofundamento financeiro, com crescimento das instituições financeiras monetárias e não-monetárias. A eficiência alocativa também cresceria e a renda seria melhor distribuída.

Nesse contexto, torna-se essencial que as forças de mercado influenciem as taxas de juros. Essas taxas devem refletir a inflação, as mudanças de preços relativos e os riscos nas economias que têm mercados de capitais abertos. A Tabela 2 mostra a influência das taxas de juros positivas e livremente determinadas no mercado sobre as taxas de crescimento de um grupo de 33 países em desenvolvimento.

Tabela 2 - Taxas de crescimento e outros indicadores econômicos em grupos de países com taxas reais de juros positivas, moderadamente negativas e muito negativas, 1974-1985.

\begin{tabular}{||c|c|c|c|}
\hline Indicadores & \multirow{2}{*}{ Positiva } & \multicolumn{2}{|c|}{ Negativa } \\
\cline { 3 - 4 } & & Moderada & Muito \\
\hline Taxa Real de Juros & 3,0 & $-2,4$ & $-13,0$ \\
\hline Taxa de Crescimento do PIB & 5,6 & 3,8 & 1,9 \\
\hline M3 / PIB & 40,3 & 34,0 & 30,5 \\
\hline Investimento / PIB & 26,9 & 23,2 & 23,0 \\
\hline Indice Inflacionário & 20,8 & 23,9 & 50,3 \\
\hline
\end{tabular}

Fonte: World Bank

As taxas reais de juros foram calculadas a partir de taxas nominais, utilizando a seguinte fórmula: $((1+r) /(1+p)-1) \times 100$

onde $r$ é a taxa de depósito e pé o indice de inflação. A inflação é expressa pelo Índice de Preços ao Consumidor (IPC). Poupança real é a poupança interna bruta deflacionada pelo IPC. 
Vale destacar que o índice médio de crescimento econômico dos países que praticam taxas de juros positivas foi bem superior aos países com taxas negativas. Desta forma, reforça-se a idéia de que a elasticidade da poupança à taxa de juros é positiva.

$\mathrm{Na}$ evolução recente do sistema financeiro internacional, ressaltam alguns aspectos importantes na definição do rítmo e da abrangência que o processo de liberalização da atividade financeira pode alcançar em um dado país. Quando analisa o modelo Mckinnon/Shaw, FRY (1988) chama atenção para o fato de que a liberalização financeira alcança melhores resultados quando as economias que venham a adotar essa medida equacionem, a priori, os problemas relativos à inflação e ao déficit orçamentário.

Este autor compara as experiências dos países emergentes da Ásia, marcadas pelo gradualismo e empenho permanente na manutenção das pré-condições macroeconômicas sugeridas por McKinnon com algumas tentativas de paises latino-americanos, feitas de forma intempestiva e sem que a inflação e o déficit orçamentário tenham sido satisfatoriamente resolvidos. As experiências recentes de países que adotaram programas de estabilização da economia com base numa âncora cambial, demonstraram que déficits na balança comercial não podem ser compensados a longo prazo por entrada de capital especulativo, como forma de fechar a conta de transações correntes.

Por um lado, torna-se importante adequar o sistema financeiro às necessidades do comércio exterior, promovendo a liberalização do sistema financeiro, para que este possa conferir maior competitividade às transações comerciais, melhorando o desempenho da balança comercial. Por outro lado, existe a necessidade de maior seletividade quanto ao 
prazo de permanência do capital que entra no mercado doméstico, aumenta as reservas internacionais e ajuda a fechar a conta de transações correntes.

BACHA (1994) propõe que o grande desafio a ser enfrentado pelos países latinoamericanos em processo de estabilização nos anos 90 será o de inibir a entrada de capital especulativo de curto prazo, sem afugentar o capital para investimentos diretos de longo prazo. Nos países emergentes da Ásia prevaleceram fortes restrições à entrada de capital especulativo de curto prazo, porém as taxas de poupança desses países são historicamente altas, o que confere um risco menor de limitação de capital para investimento, quando se discrimina o capital estrangeiro. É ocioso dizer que o Estado, via Banco Central, tem um papel essencial na definição da delicada estratégia de tratamento a ser conferido ao capital estrangeiro.

A recente globalização dos mercados cambiais e de capitais, se por um lado gerou menor restrição mundial de crédito, por outro tornou esse mesmo crédito altamente volátil e sem limites de prazo e de fronteiras. Com isso, o grau de incerteza em relação às taxas de câmbio e juros no mercado internacional aumentou substancialmente, retirando graus de liberdade das autoridades econômicas.

A coordenação de política econômica entre os bancos centrais dos países desenvolvidos se impõe. Porém há incerteza quanto às novas paridades num mundo tripolar, isto é, não se tem idéia da relação estável marco/dólar/yen. Em outras palavras, falta a base sobre a qual fazer coordenação. Isso reforça a necessidade de atuação atenta das autoridades monetárias nacionais em relação aos perigos da liberalização. 
Outros aspectos, como grau de abertura econômica, estrutura produtiva, condições políticas e situação macroeconômica são determinantes do nível de desregulamentação da atividade financeira que se pode alcançar. Posto isso, torna-se de suma importância a análise de desempenho e eficiência do sistema financeiro brasileiro em período recente para que se possa avaliar a intensidade e os limites das propostas de mudanças a serem introduzidas num cenário de estabilização econômica.

\section{2 - Sistema financeiro e estabilização no Brasil}

A reforma do sistema financeiro brasileiro é uma tarefa prioritária num cenário de estabilização da economia. Superada a crise do financiamento da dívida do setor público e restaurada a confiança dos agentes econômicos no crescimento sustentado de longo prazo, apresenta-se como uma das primeiras necessidades a reorganização do sistema de financiamento para investimentos produtivos de longo prazo.

Um ensaio da MB ASSOCIADOS (1991) sobre o sistema financeiro nacional mostra que os vários anos de desequilíbrio macroeconômico com taxas altíssimas de inflação provocaram um distanciamento do sistema da atividade de financiamento da produção. Por outro lado, observou-se uma hipertrofia desse mesmo sistema financeiro, tendo como principal atividade o carregamento de volumes cada vez maiores de títulos da dívida pública. 
O financiamento da dívida pública tornou-se uma operação bastante lucrativa e praticamente sem riscos, já que o sistema de zeragem automática junto à mesa do Banco Central garantia a geração de recursos para o fechamento das contas diariamente. Além disso, o ambiente de inflação elevada permitiu ao setor financeiro privado obter lucros expressivos, através do float.

NAKANO (1992), sugere que essas distorções foram responsáveis pelo exagerado aumento de participação do sistema financeiro brasileiro no PIB. Em 1970 a sua participação era de 6,4\%. Em 1985 passou para 12,4\%, e em 1989 atingiu a impressionante marca de 19,0\%. Em países desenvolvidos, com inflação baixa, esta proporção gira em torno de $5 \%$.

O Plano Real, utilizando uma âncora cambial, tem sido eficaz no controle da escalada do processo inflacionário, reduzindo drasticamente a lucratividade do sistema financeiro. No entanto, vários autores têm apontado para a necessidade da obtenção de uma âncora fiscal, para que o Plano possa caminhar no sentido da desindexação e da estabilização definitiva.

Uma reforma fiscal que promova o equilíbrio das contas públicas e devolva ao Estado brasileiro a capacidade de autofinanciamento, implicará uma grande redução na atividade de financiamento da dívida pública, minguando assim a outra fonte básica de recursos do setor financeiro nacional.

Depreende-se desses fatos a urgência da reforma do sistema financeiro nacional. Não se pode deixar de considerar porém que o sistema financeiro cresceu, mas também 
se sofisticou em termos operacionais (modernas tecnologias nas áreas de informática e telecomunicações) e na criação de novos instrumentos financeiros.

Assim sendo, a reforma do sistema financeiro deve levar em consideração as mudanças subjacentes ao processo de estabilização econômica. MENDONÇA DE BARROS (1994) relaciona entre essas mudanças: a maior importância do mercado de capitais, com ênfase no processo de securitização; menor restrição ao volume e prazo de crédito; maior seletividade no financiamento, privilegiando o tomador do empréstimo e não a atividade financiada; e, fortalecimento dos investidores institucionais (fundos de pensão e seguradoras).

O processo de securitização, ou seja, a colocação de commercial papers e bônus de médio e longo prazos lastreados no fluxo de faturamento do tomador de crédito, deve ser intensificado num cenário de estabilização, uma vez que possibilitará boa oportunidade de capitalização para muitas empresas. Isso implica que os bancos não terão apenas o papel de transferir a poupança entre agentes na economia. Deve-se estar atento, portanto, aos riscos embutidos no aumento da vulnerabilidade das economias modernas aos distúrbios dos sistemas financeiros, aliados à expansão global da atividade especulativa.

O processo de abertura da economia, aliado ao fim do período de alta inflação, proporciona um maior volume de operações de crédito em dólares e também de linhas de longo prazo. Sendo assim, o sistema financeiro deve estar preparado para atuar num ambiente de incerteza quanto às taxas internacionais de câmbio e juros. 
Necessariamente, o sistema financeiro deverá atuar com maior grau de seletividade em relação ao crédito. Dado o caráter de fungibilidade do crédito, impõe-se que seja priorizada na análise dos empréstimos a capacidade de pagamento do tomador e não a atividade para a qual o crédito será concedido. No que se refere ao volume de crédito para o financiamento produtivo de longo prazo, o surgimento de grandes investidores institucionais (fundos de pensão e seguradoras) poderá sem dúvida ampliar a capacidade do sistema financeiro em alavancar poupança financeira e aumentar a taxa de investimento.

Num cenário de estabilização, a tendência do sistema financeiro será a de maior especialização. As atividades principais às quais o sistema financeiro deverá se dedicar são: operações nos mercados de capitais, fornecimento de crédito ao setor privado, inclusive o agrícola, operações com títulos da dívida pública, serviços de " personal banking ", arbitragem de títulos e moedas, instrumentalização de operações com recursos externos e repasses diversos, conforme sugere o ensaio da $\mathrm{MB}$ ASSOCIADOS (1991).

Para a agricultura, será de fundamental importância a implantação de carteiras de crédito rural nos principais bancos privados. É preciso ter em conta que, qualquer que seja o novo modelo a ser implantado para o crédito rural, este continuará sendo operado em boa parte pelo setor bancário, devido a sua capilaridade e a natureza das garantias normais do setor (hipotecárias e pignoratícias, além das garantias pessoais). 
A restruturação do sistema financeiro brasileiro certamente definirá uma série de características da nova organização do sistema de financiamento agrícola. No entanto, é necessário compatibilizar as mudanças que a estabilização impõe às lições aprendidas dos erros do passado.

\section{3 - Financiamento rural no Brasil}

A organização do SNCR ocorreu em meados dos anos 60 , juntamente com o restante do Sistema Financeiro Nacional. Em 1965, a Lei 4829 estabelece que: "as taxas de juros das operações sob qualquer modalidade de crédito rural serão inferiores em pelo menos $1 / 4$ das taxas adotadas para as operações bancárias de crédito mercantil" (Artigo 14, Parágrafo Único). Outra medida no âmbito do sistema financeiro que visava favorecer a agricultura foi a Resolução 69 do BACEN em 1967, que estabelecia que $10 \%$ dos depósitos líquidos à vista seriam obrigatoriamente aplicados em crédito rural.

DIAS \& AMARAL (1990) ao comentarem a criação do SNCR, que estabelecia um complexo sistema de credenciamento de operações e de produtores rurais elegíveis como mutuários, salientam que, de todo o sistema financeiro, o crédito rural foi o segmento mais tutorado pelo Governo, pois o Conselho Monetário Nacional era a única Autoridade constituída para limitar o volume de empréstimos do Banco do Brasil.

Vale ressaltar que não havia nessa época nenhum sistema de incentivo fiscal acoplado à captação de recursos para o crédito rural. $\mathrm{O}$ volume de recursos dependia 
pesadamente dos depósitos à vista e dos empréstimos criados via "conta movimento" do Banco do Brasil. A inexistência de uma fonte permanente e exclusiva de recursos para o crédito rural é hoje apontada como a principal razão do enfraquecimento do sistema de financiamento rural no final da década de 70 .

BARROS (1990) argumenta que o estabelecimento de juros diferenciados para a agricultura foi, na verdade, uma medida compensatória para um setor fortemente penalizado durante o processo de substituição de importações, quando as restrições quantitativas ao comércio e a sobrevalorização cambial eram formas implícitas de taxação da agricultura.

BRANDÃO (1989), estimou que 8 a $9 \%$ da renda agrícola foram transferidos para o setor não agrícola entre 1975 e 1983 através das distorções de preços de produtos e insumos, decorrentes de tazações explícitas e implícitas, e da política fiscal. Ao mesmo tempo, constatou uma inversão no sentido da transferência de recursos quando se considera a política de crédito rural: a agricultura teria recebido, nesse último cenário um fluxo líquido de recursos de valor correspondente a 5 a $6 \%$ da renda setorial.

Com a perda da capacidade de poupança do Governo no final da década de 70, o Estado reduz as suas aplicações em crédito rural oriundas do orçamento monetário, como se observa na Figura 2.

A partir do início da década de 80 os recursos oriundos das exigibilidades sobre depósitos à vista sofreram uma forte redução no volume, em função do recrudescimento do processo inflacionário. O governo passa a emitir títulos públicos para captar recursos, 
aumentando a participação do Tesouro Nacional no financiamento rural. Nesta época também se inicia uma substituição do crédito rural subsidiado por um Programa de Garantia de Preços Mínimos (PGPM) mais realista e consistente, como principal instrumento de política agrícola no País.

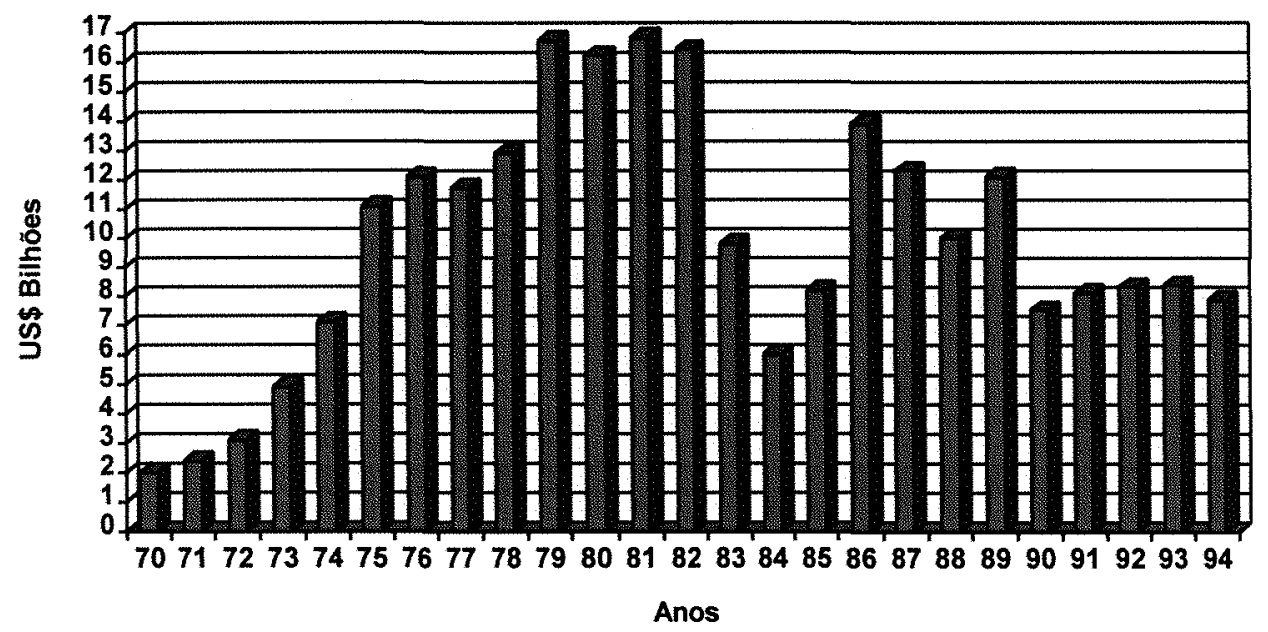

Fonte: Bacen

Não inclui Fundo de Commodities nos anos 1993 (US\$2,05 bilhões) e 1994 (US\$ 4,15 bilhões).

Figura 2 - Evolução do crédito rural no Brasil, 1970-1994.

Entre 1980 e 1984 é introduzida no crédito rural a correção monetária parcial das dívidas. Em 1985 chega-se a correção monetária plena mais crédito suplementar a taxas livres. Com o Plano Cruzado, as taxas para o financiamento agrícola são novamente fixadas em termos nominais. Em 1987, verifica-se uma mudança na estrutura das fontes 
do financiamento agrícola. Neste ano a Caderneta de Poupança Rural passa a ganhar importância em relação às outras fontes.

Em 1990, pela primeira vez desde a vigência do SNCR é anunciada uma tentativa de se criar uma fonte de recursos exclusiva para financiar a agricultura. A Lei 8023 que reformula o Imposto de Renda (IR) sobre as atividades rurais previa a vinculação dos recursos arrecadados por esse imposto a um fundo fiscal para financiar a agricultura. Os recursos para o setor seriam então captados nele próprio e de acordo com sua capacidade contributiva, ressalvada a justiça fiscal. No entanto, mesmo com a medida provisória 167, que visava colocar a Lei em vigor, o fundo fiscal não passou de uma intenção, não tendo sido regulamentado até hoje. Esse fundo teria a característica de servir de alternativa de cobertura para uma descontinuidade dos recursos oficiais.

Em 1993 é introduzido o sistema de custeio via equivalência-produto. Esse sistema consiste em vincular o pagamento do financiamento agrícola a quantidades fixas do produto financiado. Para tanto, converte-se o valor do financiamento em quantidade de produto através de um preço de referência. $\mathrm{Na}$ data de vencimento do contrato, a quantidade pactuada é transformada em moeda corrente para que a liquidação seja efetuada.

Estudo do BANCO DO BRASIL (1993) demonstra que esse sistema onera o Tesouro Nacional, pois a diferença de preços na entresafra (quando o empréstimo é tomado) e na safra (quando é liquidado) seria apropriada pelo produtor e o agente financeiro repassará o prejuízo para o Tesouro. 
O volume embutido nesse subsídio implícito poderia ser muito alto nos anos em que os produtos agrícolas tivessem preços baixos e as taxas de juros se fossem elevadas. Além disso, a demanda por crédito formal cresceria enormemente, pois não haveria risco de crédito para os produtores. MENDONÇA DE BARROS \& PESSÔA (1993) estimaram que para a safra 91/92, caso esse sistema estivesse implantado, o Tesouro teria que arcar com US\$1,5 bilhão.

A constatação maior desta breve revisão do SNCR é de que esse programa está exaurido. Ao mesmo tempo, alguns autores argumentam que o programa de crédito rural vem sendo desativado porque já teria cumprido o papel para o qual fora pensado. $O$ SNCR teria tido êxito em acomodar os interesses da agroindústria, compensando os produtores rurais por perdas durante o processo de substituição de importações e criado uma massa crítica de agricultores para absorver e disseminar as novas tecnologias e técnicas modernas de decisão empresarial.

Contra essa posição, existe o argumento de que uma descontinuidade nesse programa, por ele já ter realizado seu objetivo, deveria ser de forma gradual, passando-se lentamente a outro sistema alternativo que esteja mais ajustado ao novo momento vivido pela agricultura nacional. No entanto, tal não vem ocorrendo, o que reforça a tese de que o programa se esgotou devido à crise fiscal e à perda da capacidade de poupança do Governo Federal.

Nesse contexto torna-se evidente a necessidade do setor privado atuar no financiamento agrícola através da intermediação financeira. No entanto, os bancos no 
Brasil têm grande receio da intervenção estatal na política de crédito como ocorreu em 1987 e 1988, anos em que foram também concedidas anistias das dívidas dos produtores rurais. Além dessas intervenções do governo, houve uma depressão nos preços agrícolas e frustações de safras no início da década de 90 , o que contribuiu sobremaneira para aumentar a inadimplência dos produtores junto aos bancos.

A conseqüência imediata da conjugação dessas circunstâncias foi um racionamento cada vez maior no mercado formal de crédito rural. Ademais, as regras de correção dos financiamentos e a real disponibilidade de recursos tornaram-se cada vez mais duvidosas.

As propostas de um novo sistema giram em torno de dois temas básicos: reestruturação do atual SNCR, privilegiando a maior participação do setor privado nas operações de financiamento agrícola; e, desregulamentação das normas do crédito rural, com o intuito de reduzir os custos do financiamento.

\section{4 - Reestruturação do crédito rural}

O desenho do novo sistema de crédito rural deve objetivar menor intervenção do Estado nos mercados de crédito e de produtos agrícolas e quando a presença do Estado for indispensável, que essa se dê sem fazer uso de recursos inflacionários. Outro aspecto fundamental é a definição do futuro do Banco do Brasil, que durante várias décadas foi (e ainda é) o principal vetor de financiamento agrícola no país. 
Algumas propostas de reformas tem sido apresentadas nesta área: i) criação de um fundo que capte recursos oriundos do próprio setor agrícola a taxas atrativas; ii) flexibilização das normas que regem atualmente o crédito rural, para facilitar a atuação de cooperativas de crédito; iii) incentivo ao uso dos novos instrumentos de crédito mercantil, tais como o Certificado de Mercadoria com Emissão Garantida (CM-G) e a Cédula de Produto Rural (CPR); e, iv) criação de uma linha de redesconto para carteiras agrícolas das instituições financeiras que trabalham com crédito agrícola, facilitando a maior participação do setor bancário privado no financiamento da atividade agrícola.

A Lei 8023, que reformula o IR sobre atividades rurais, estabelece a vinculação dos recursos arrecadados por esse imposto a um fundo fiscal para financiar a agricultura. Ao propor a criação desse fundo, BARROS (1990) explica que proporcionalmente ao volume de depósitos nesse fundo, os produtores teriam direito a isenções fiscais quando do recolhimento do imposto de renda.

Os recursos disponíveis nesse fundo ficariam a disposição do Estado para usá-los no financiamento agrícola. Esse mecanismo estimularia a implantação de um imposto de renda agrícola mais eficaz do que o atual, e que na prática só existe na Lei. O atrelamento da contribuição ao gasto público no próprio setor estimularia, por outro lado, maior aquiescência à Lei.

BARROS (1990) demonstra que a cobrança desse imposto sobre uma parcela relativamente pequena do universo de agricultores seria suficiente para em poucos anos 
acumular recursos para financiar todos os agricultores. Em boa parte, esse fato reflete a alta concentração de renda na agricultura brasileira.

DIAS \& AMARAL (1990) encorajam a alternativa de estimular o crédito cooperativo. Lembram esses autores que as cooperativas atualmente têm funcionado como verdadeiras carteiras agrícolas dos bancos, repassando recursos para pequenos agricultores. Finalmente, sugerem que as restrições de ordem legal que impedem as cooperativas de possuirem bancos deveriam ser eliminadas, aumentando a concorrência na intermediação financeira.

NAKANO (1992) sugere que os bancos privados sempre classificam a atividade agrícola como de alto risco e, em função disso, costumam praticar elevadas taxas de juros nas operações com o setor. Assim sendo, ter-se-ia uma espécie de seleção adversa, ou seja, apenas os produtores que aceitam altos riscos continuariam buscando financiamento nos bancos. A tendência seria de crescimento da inadimplência juntamente com o maior racionamento de créditos.

Esse mesmo autor também sugere como alternativa de financiamento, no âmbito de uma reforma do sistema financeiro, a ampliação das atividades das cooperativas de crédito, possibilitando sua transformação em pequenos bancos regionais de crédito cooperativo. Esses bancos regionais atuariam de forma integrada sob a coordenação de um banco federal de crédito cooperativo, criado e controlado pelas próprias cooperativas e supervisionado pelo Banco Central. 
Para constituir um fundo com recursos necessários para a capitalização inicial desse banco federal, NAKANO (1992) sugere que o Tesouro Nacional conceda um empréstimo de longo prazo, com base nos recursos do Orçamento de Crédito, que seria então extinto. Vale ressaltar que o modelo de crédito cooperativo norte-americano foi capitalizado no início com um empréstimo de longo prazo do Tesouro dos Estados Unidos, como relatam DURÁN \& LOPES (1992).

Outra fonte de recursos apontada por NAKANO (1992) derivaria de pequenos empréstimos de longo prazo dos próprios agricultores. Também aqui vale o registro de DÚRAN \& LOPES (1992) que o sistema alemão de crédito cooperativo foi constituído a partir de empréstimos dos próprios produtores.

NAKANO (1992) defende ainda que os bancos cooperativos devem atuar sempre com o propósito de reduzir custos operacionais, contudo, não devem ser expostos à competição dos bancos comerciais que, para reduzir custos fixos das operações, prestam múltiplos e sofisticados serviços. $\mathrm{O}$ banco cooperativo deve ser visto como mais um serviço que a cooperativa presta aos seus cooperados.

O banco cooperativo pode transformar-se num braço forte para a implantação definitiva de instrumentos de crédito mercantil. O banco cooperativo pode usar de forma mais eficiente os certificados de mercadorias (CM-G e CPR) que existem no mercado, pois certamente contará, em seu quadro de pessoal, com especialistas em comercialização agrícola. 
A utilização desses instrumentos, fortalecendo a formação de mercados spot, é apontada como o primeiro passo para a criação de mercados futuros de produtos agrícolas em bolsa que operem com volume e liquidez. Essa implantação traria um aumento significativo no volume de crédito para o setor agrícola e também a possibilidade de proteção contra o risco de preço (hedge), que afeta diretamente a renda da agricultura, devido à inelasticidade-preço nos mercados de produtos agrícolas.

Uma das mais importantes consequências da implantação desses mercados seria uma elevação da participação das tradings no financiamento direto da produção agrícola. Tanto nos Estados Unidos quanto na Argentina esses agentes são os mais importantes financiadores da atividade primária e para que isso ocorra também no Brasil só faltam os intrumentos adequados.

A grande dificuldade para que o crédito cooperativo se torne uma realidade no Brasil reside na fragilidade do sistema cooperativista nacional, onde as cooperativas agrícolas de produção não decolaram e enfrentam dificuldades financeiras e as cooperativas de crédito rural não estão ainda preparadas para atuar em larga escala.

É bastante provável que a mudança mais sensível no sistema de crédito rural deverá ocorrer no contexto da reforma do sistema financeiro como um todo. Isto significa ser inadiável a desregulamentação/desburocratização do crédito rural, objetivando principalmente a efetiva participação dos bancos privados e a maior eficiência dos bancos oficiais. 
DIAS \& AMARAL (1990) apontam que a criação de carteiras especializadas de crédito rural poderia ser estimulada pela possibilidade de empréstimo interbancário para os recursos destinados ao crédito rural, além da criação de uma linha de redesconto junto ao Banco Central. DIAS (1993) sugere que para terem acesso a essas linhas especiais de redesconto, os bancos privados teriam que montar sistemas operacionais nas suas carteiras agrícolas semelhantes ao das operações que realizam com o comércio e a indústria.

Como pano de fundo de todas as mudanças sugeridas, coloca-se em discussão a questão da eficiência microeconômica nas operações do crédito rural e o nível de taxas de juros com que as instituições financeiras devem trabalhar. DÚRAN \& LOPES (1992) dividem a taxa de juros cobrada pelas instituições de crédito em três componentes básicos: o custo de captação, a margem operacional da entidade financeira (ambos associados aos custos de transação) e um prêmio de risco para cobrir a possibilidade de inadimplência do tomador.

A atividade agrícola é uma atividade de risco por excelência, portanto sempre haverá um prêmio de alto risco para o setor, que poderá ser atenuado por uma boa avaliação da capacidade de pagamento de cada tomador, em particular, e por instrumentos como seguro agrícola e hedge. Os dois primeiros elementos que compõem a taxa de juros podem ser reduzidos, aumentando-se a eficiência do agente financeiro nas operações de captação, empréstimo e recuperação dos recursos destinados ao crédito rural. 
Torna-se então muito importante estabelecer critérios para avaliar a eficiência dos agentes financeiros, via estimação dos custos de transação do crédito rural. Um esforço de pesquisa nessa direção, certamente, será de grande valia para que o setor financeiro estabeleça as bases essenciais a uma parceria duradoura e vantajosa com os produtores rurais. 


\section{3 - REFERENCIAL TEÓRICO}

\section{1 - Custos bancários de transação no crédito rural}

Toda e qualquer intermediação financeira entre agentes econômicos incorre em custos. É possível demonstrar graficamente o impacto desses custos sobre a oferta de crédito através da Figura 3.
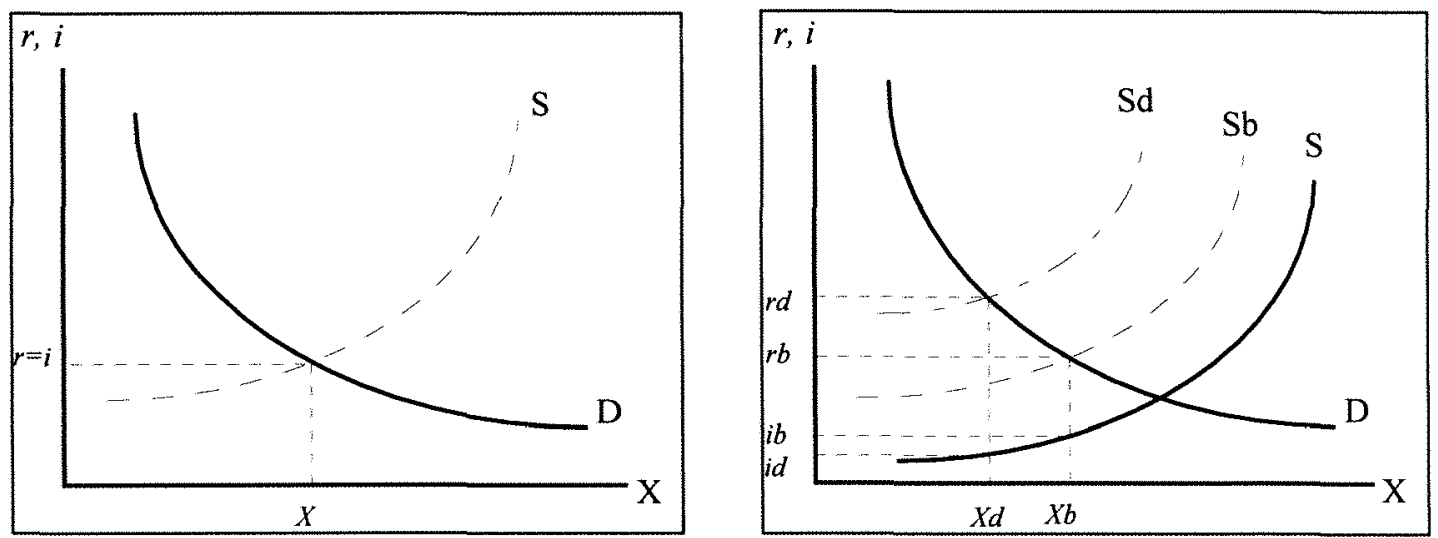

Fonte: World bank (1989)

Figura 3 - Oferta e demanda de crédito. 
Nos diagramas da Figura 3, o eixo horizontal mede a quantidade de empréstimos tomados ou concedidos por unidade de tempo $(\boldsymbol{x})$, enquanto o eixo vertical mede o custo de tomar emprestado $(\boldsymbol{r})$ e o retorno gerado pelos empréstimos $(\boldsymbol{i})$.

No primeiro diagrama, a procura de crédito na economia é representada pela curva descendente D. A inclinação dessa curva reflete a quantidade crescente (por unidade de tempo) de investimentos rentáveis à medida que diminui o custo dos empréstimos.

A curva ascendente $\mathbf{S}$ representa a oferta de crédito na economia, isto é, a quantidade de poupança oferecida a terceiros, seja diretamente ou através de intermediários, como os bancos. Sua inclinação positiva se deve ao aumento da poupança disponível para aquisição de ativos financeiros à medida que o retorno sobre estes últimos aumenta em relação ao retorno proporcionado por bens reais ou por investimentos fora do País.

Se não existissem custos transacionais nem regulamentação de juros, a taxa de juros determinada pelo mercado seria $\boldsymbol{r}=\boldsymbol{i}$, e a quantidade de crédito por período seria $\boldsymbol{x}$. Contudo, a tarefa de buscar bons mutuários custa dinheiro aos bancos/intermediários.

No segundo diagrama, o valor que os bancos têm que cobrar dos mutuários para se ressarcirem desse custo é representada pela curva $\boldsymbol{S d}$. A distância vertical entre essa curva e a curva $\mathbf{S}$ da oferta de fundos representa o valor desses custos transacionais (inclusive o custo de cobertura de inadimplências). Se os credores tivessem que encontrar mutuários por si próprios, estariam dispostos a oferecer $X \boldsymbol{d}$ na expectativa de 
ganhar id (após deduzidos os custos esperados). Os mutuários estariam pagando $\boldsymbol{r d}$ por esse volume de crédito.

O custo de transação introduz, assim, uma diferença entre o custo para o mutuário e o retorno do poupador, fazendo diminuir a quantia emprestada. Até certo ponto, a existência dos bancos ou outros intermediários resulta do fato dos mesmos poderem reduzir os custos transacionais de emprestar e tomar emprestado. É o que nos mostra a curva $\boldsymbol{S b}$. A margem entre o custo para o mutuário e o retorno do credor é agora a sobretaxa cobrada pelo banco.

Supondo-se que as sobretaxas cobradas pelos bancos sejam menores que o custo de emprestar diretamente, a quantia emprestada aumenta de $\boldsymbol{X d}$ para $\boldsymbol{X b}$, o retorno dos credores aumenta de $\boldsymbol{i} \boldsymbol{d}$ para $\boldsymbol{i b}$ e o custo do empréstimo para os mutuários cai de $\boldsymbol{r} \boldsymbol{d}$ para $\boldsymbol{r b}$.

Quanto mais os bancos forem capazes de reduzir os custos de transação, maiores serão esses efeitos. O mesmo ocorre quando o Governo reduz os encargos exigidos dos bancos, tais como reservas compulsórias não-remuneradas, que entram na composição desses custos.

Custo de transação pode ser definido como a soma dos custos que os agentes financeiros têm que arcar para que os contratos vigentes sejam cumpridos satisfatoriamente em suas operações ativas e passivas. Isso inclui coleta de informações sobre o tomador e sua atividade, planejamento e monitoramento das condições de preço (juros) e prazo dos contratos, custos administrativos (folha de pagamentos e aluguel), 
impostos, custo de capital e cumprimento das normas estabelecidas pelas autoridades monetárias, além de uma reserva para cobrir eventuais perdas por inadimplência.

Para cobrir os custos de transação as instituições financeiras cobram taxas por esses serviços específicos e um spread sobre os juros pagos aos poupadores. CUEVAS (1988) explica que os juros bancários devem incluir, além dos custos de transação, a margem de lucro do banco na intermediação.

Para MEYER \& CUEVAS (1990), o custo bancário de transação corresponde à remuneração dos recursos humanos e materiais utilizados pelos bancos nas suas operações de crédito rural, compreendendo desde a obtenção do dinheiro junto ao poupador, passando pela sua aplicação junto ao tomador do empréstimo, até a sua recuperação quando do vencimento do contrato. Os custos de transação podem ser separados em dois blocos. O bloco dos custos de mobilização de depósitos, que compreende os custos dos recursos (trabalho, capital, materiais) utilizados no manuseio de contas de depósitos, documentação, registro e publicação de balanços. O segundo bloco compreende os custos de concessão de créditos, que estão associados ao processamento do empréstimo e gastos com monitoramento e recuperação do mesmo.

Ao analisar de forma mais abrangente os custos de transação, ADAMS (1994) considera que esses são compostos por gastos implícitos e explícitos dos diversos agentes envolvidos nos mercados financeiros formais. $\mathrm{O}$ autor exclui da composição dos custos de transação os gastos com pagamentos de juros, custo dos fundos e perdas de empréstimos. Além disso, subdivide os custos de transação em: custo de oportunidade, 
que corresponde ao tempo gasto por tomadores e depositantes durante a negociação de contratos financeiros e as despesas explícitas dos participantes ao realizar e cumprir estas obrigações.

Conhecer a estrutura de custos é de suma importância para que os agentes financeiros possam avaliar o desempenho das linhas de crédito e para desenvolver técnicas gerenciais adaptadas ao leque de serviços prestados por suas agências. A lucratividade desses serviços está diretamente relacionada com a evolução desses indicadores de custos. As decisões gerenciais referentes à ampliação ou redução de determinadas atividades, implantação de novos serviços, devem ter como base o conhecimento de importantes aspectos tecnológicos, tais como economia de escala (entendida como a redução do custo total médio quando se aumenta a escala de produção da firma) e de escopo (entendida como redução do custo total médio quando se aumenta o número de produtos e/ou serviços produzidos pela firma), bem como o estado da arte da alocação dos recursos do banco entre funções alternativas ou complementares.

MEYER \& CUEVAS (1990) citam como fatores relevantes na determinação da magnitude dos custos de transação o grau de desenvolvimento do sistema financeiro e o nível de regulamentação do setor. Quanto mais amplo e sofisticado o sistema financeiro, maior será a disponibilidade de tecnologias de informática e de telecomunicações e, consequentemente, menor o custo de obtenção e processamento de informações. Quanto menor o grau de regulamentação do setor, envolvendo desde instrumentos de captação e aplicação, taxas e impostos, segmentação de mercado até o aparato legal, maior será a 
agilidade do sistema, proporcionando ganhos de produtividade e reduzindo os custos. Por sua vez, a escala de operação e a diversidade de serviços oferecidos são também fatores fundamentais na determinação dos custos de transação.

ADAMS (1987), aponta a pulverização espacial, o pequeno tamanho médio dos empréstimos, a falta de boas garantias e o alto risco da atividade agrícola como fatores que colocam a operacionalização do crédito rural entre as operações mais custosas nos mercados financeiros formais. A dificuldade de avaliar a capacidade de pagamento de cada produtor em separado, em função da assimetria de informações entre este e o intermediário financeiro e o fato dos pequenos agricultores tomarem empréstimos de forma descontínua e sempre em pequenos valores também constituem sérios problemas na observação de ADAMS \& ROMERO (1987).

Afora esses problemas estruturais, muitos países adicionam problemas institucionais aos agentes financeiros, como por exemplo, a obrigatoriedade da prestação de assistência técnica, na forma de crédito supervisionado/orientado, e a imposição de taxas de juros concessionárias, que é também uma distorção muito freqüente. Consequentemente, os intermediários embutem em seus custos de transação um percentual referente a preparação de contratos que limite o risco da atividade, custos do monitoramento e acompanhamento dos contratos, além dos custos de perdas eventuais. A ampliação da atividade de financiamento depende, portanto, do quanto é possível reduzir esses custos, via dispositivos legais, culturais e institucionais. 
Os custos de transação mais as perdas esperadas de empréstimos não recuperados, as reservas compulsórias e a tributação são responsáveis diretos pelo diferencial existente entre as taxas de captação e de concessão de empréstimos. Esses diferenciais variam de acordo com o grau de amplitude e o risco da atividade financiada.

Em países desenvolvidos, com um amplo e sofisticado sistema financeiro, a diferença entre o custo de captação dos recursos e a taxa pela qual esses são repassados ao tomador giram em torno de $3 \%$ a $4 \%$. Nos países em desenvolvimento com baixa inflação, esse diferencial é praticamente o mesmo. No entanto, os custos de captação dos fundos tendem a ser mais elevados, assim como o custo do empréstimo para o tomador. Isso ocorre em geral porque o sistema financeiro desses países ainda não atingiu o mesmo grau de desenvolvimento dos países de alta renda.

Os países em desenvolvimento com altas taxa de inflação tendem a apresentar um diferencial bastante elevado, acima dos $10 \%$, pois além de compulsórios elevados, operam com custos de transação bastante altos. Países de baixa renda também apresentam um grande diferencial entre taxas para o credor e o tomador, pois as dificuldades de levantar boas informações, os altos riscos da atividade com baixo uso de tecnologia bancária e a utilização ineficiente de insumos humanos e materiais na geração de serviços financeiros contribuem, sobremaneira, para a elevação dos custos de transação.

GONZÁLEZ VEGA \& GARITA (1987) admitem que quando os custos de transação são elevados, toda a sociedade está perdendo recursos, pois o custo total dos 
fundos é elevado para os tomadores, o rendimento líquido dos depositantes é baixo e a rentabilidade dos intermediários é reduzida em última instância.

\section{2 - Custos de transação e racionamento no crédito rural}

O custo de transação também exerce o papel de racionador de crédito. ADAMS \& NEHMAN (1979) afirmam que quando os recursos financeiros são emprestados a taxas de juros baixas, cria-se uma situação de excesso de demanda por crédito e o custo de transação pode ser utilizado pelas instituições financeiras formais como um desestímulo aos pequenos tomadores. O tamanho dos mercados formais pode ser, portanto, reduzido quando os custos de transação são elevados para credores e tomadores, como acontece em países em desenvolvimento com alta inflação, segundo GONZÁLEZ VEGA (1987).

O alto custo de transação para o tomador, no crédito rural brasileiro é apontado por ARAÚJO \& ALMEIDA (1992) como um dos fatores que contribuem para que boa parte dos pequenos produtores procure os mercados informais de crédito. Quando as taxas de juros são elevadas e existe concorrência entre os intermediários financeiros, reduz-se a demanda por crédito formal. Logo, esses intermediários precisam ser estimulados a reduzir o custo de transação para conquistarem novos tomadores, incluindo pequenos e médios. 
GRAHAM \& FIRESTINE (1987) sugerem ser necessário eliminar situações crônicas de excesso de demanda por crédito para que os bancos sejam estimulados a reduzir os custos de transação, os quais nesta circunstância são elevados para funcionar como elemento de racionamento de crédito.

Por seu turno, é bastante comum a utilização de racionamento de crédito rural para os pequenos agricultores via elevação dos custos de transação. GONZÁLEZ VEGA (1987) relaciona entre os mecanismos para realizar esse racionamento: redução no número de empréstimos a novos tomadores, preferência aos grandes agricultores que possuem melhores garantias e concessão de créditos de curto prazo e com menor risco.

Para diminuir os custos de transação para os pequenos produtores, pode-se lançar mão da concessão de empréstimos para grupos de tomadores. Desta forma, os agentes financiadores reduzem o custo de transação fazendo um só empréstimo. A inadimplência será menor e também o custo de recuperação do empréstimo. Os serviços de assistência técnica e monitoramento ficam também reduzidos, assim como o custo de transação para os tomadores.

Alguns fatores podem ser apontados como mecanismos de elevação dos custos de transação. Entre eles, destacam-se: burocracia excessiva; desconhecimento da atividade financiada; falta de informações cadastrais atualizadas dos agricultores/mutuários; sistemas ineficientes de sanções contra inadimplentes e alta taxas de inflação. Para reduzir esses custos é preciso, primeiro, ter consciência de que eles existem e depois 
desenvolver soluções técnica e economicamente viáveis para enfrentá-los. Não é rápido nem barato ser eficiente no processo de diminuição dos custos bancários de transação.

Normalmente, as instituições de crédito enfrentam um excesso de demanda e aplicam regras de racionamento, como por exemplo, o aumento do valor mínimo dos empréstimos. Freqüentemente esse racionamento exclui da linha de crédito justamente aqueles tomadores para quem foram destinados os recursos, ou seja, pequenos e médios tomadores. As instituições, domésticas ou estrangeiras, que alocam originalmente os recursos em bancos de desenvolvimento, deveriam estar atentas aos níveis de custo de transação com que operam esses bancos e aprimorar os procedimentos exigidos nos empréstimos.

LADMAN (1987) define como Sistema de Entrega de Crédito (SEC) as condições do empréstimos e os procedimentos seguidos pelo credor para oferecer, administrar e cobrar os mesmos. Os bancos agrícolas de desenvolvimento tem um SEC complexo, pois incluem o crédito supervisionado que impõe serviços de acompanhamento da atividade financiada e dos próprios mutuários, além de uma complicada documentação com objetivos de controle interno e determinação de responsabilidades.

Esses bancos poderiam reduzir o SEC através de práticas de terceirização dos serviços de assistência técnica e de informação de mercados. Poderia ainda investir na desburocratização dos procedimentos usados na análise e deferimento dos pedidos de 
financiamento. No entanto, a possibilidade de usar o custo de transação como fator de racionamento de crédito tem atuado, muitas vezes, contra a redução do SEC.

Quando discutem as perspectivas do crédito rural no Brasil num cenário de estabilização da economia, BARROS \& ARAÚJO (1991) recomendam como forma complementar de crédito rural, programas dirigidos aos pequenos produtores, financiados com recursos públicos orçamentários e do Tesouro Nacional, cedidos a taxas de juros preferenciais, tendo em vista as questões de pobreza rural e os desequilíbrios regionais de renda. Considerando que o crescimento da participação do setor bancário privado na oferta de crédito rural ocorre preferencialmente em regiões que concentram produtores mais capitalizados e que operam em larga escala, deve-se implementar o uso de linhas públicas de crédito para atender as regiões e/ou produtores de baixa renda que operam em pequena escala.

Portanto, reduzir o SEC das instituições públicas que operam essas linhas deve ser uma orientação sempre presente no sistema de crédito rural. O desenvolvimento de técnicas de quantificação e análise de custos de transação é importante instrumento de apoio para que bancos públicos e privados implementem programas de redução dos custos de transação. 


\section{3 - Estimativas Anteriores}

MEYER \& CUEVAS (1990) relatam estimativas de custos bancários de transação por unidade monetária de empréstimo no crédito rural para diversos países, quais sejam: Bangladesh $(0,9 \%$ a $2,9 \%)$, Filipinas $(1,6 \%$ a $5,4 \%)$, Honduras $(3,4 \%$ a $10,0 \%)$, República Dominicana $(8,8 \%)$, Togo $(5,3 \%)$ e Nigéria $(9,5 \%)$.

Barros e Araújo (1991) aplicaram um modelo de regressão múltipla para estimar as relações entre o custo bancário de transação no crédito rural e alguns fatores econômicos em 25 agências de 4 bancos que operam no Brasil. O modelo utilizado é o da equação abaixo:

$C T=f(v t, v m c, p c r)$, onde:

$C T=$ custo de transação médio da agência bancária;

$v t=$ volume total de crédito rural concedido;

$v m c=$ valor médio do contrato; $\mathrm{e}$,

$p c r=$ proporção de aplicações em crédito rural.

Para a composição dos custos de transação $(C T)$ as despesas das agências foram divididas em dois tipos básicos, quais sejam:

(a) despesas diretas, incluindo ( $\left(\mathbf{a}_{1}\right)$ despesas com pessoal; e, ( $\left.\mathbf{a}_{2}\right)$ despesas específicas de crédito rural

(b) despesas indiretas, incluindo $\left(\mathbf{b}_{1}\right)$ despesas com pessoal envolvido com outras atividades; $\left(\mathbf{b}_{2}\right)$ despesas fixas da agência; e, $\left(\mathbf{b}_{3}\right)$ despesas variáveis da agência. 
Em $\left(\mathbf{a}_{2}\right)$ estão incluídos custos com contratação de serviços de terceiros para avaliação, fiscalização, assistência técnica, peritagem, diárias de funcionários, combustíveis, lubrificantes, taxas e impostos. Em $\left(\mathbf{b}_{2}\right)$ constam gastos com aluguel, água e esgoto, luz, imposto predial, manutenção e limpeza. Já em $\left(\mathbf{b}_{3}\right)$ estão relacionados custos com impressos, formulários, comunicações, reprografia e publicidade.

$\mathrm{O}$ volume de recursos aplicados pela agência em crédito rural $(v t)$ indica as possibilidades de se explorar melhor o tamanho da carteira. Os autores constataram que, para a amostra analisada, um aumento de $10,0 \%$ em $(v t)$, coeteris paribus, tende a reduzir o $(C T)$ em $3,7 \%$. O valor médio do contrato $(v m c)$ indica a capacidade da agência em reduzir o uso de recursos materiais e humanos necessários para emprestar em crédito rural. A amostra analisada demonstra que para cada aumento em $(v m c)$ de $10,0 \%$, coeteris paribus, tende a ocorrer um aumento de apenas $3,0 \% \mathrm{em}(C T)$.

A proporção das aplicações totais da agência correspondente ao crédito rural (pcr) indica a possibilidade da agência alocar melhor seus recursos entre o setor de crédito rural e os demais. A agência que possuir aplicações diversificadas poderia realocar recursos humanos e materiais entre o crédito rural e outras atividades conforme a demanda por esses serviços. Como o crédito rural tem demanda estacional, é importante realocar recursos para outras atividades quando sua demanda for pequena e vice-versa. A estimativa de BARROS \& ARAÚJO (1991) mostrou que para a amostra analisada, um aumento de $10,0 \%$ em (pcr), coeteris paribus, tende a elevar $(C T)$ em $1,5 \%$. 
A conclusão a que chegam os autores é de que o sistema bancário, ao seguir as recomendações da eficiência econômica, deve atuar com grupo de produtores e/ou regiões que permitam ganhos de escala, com $(v t)$ e $(v m c)$ elevados e onde possa haver uma diversificação de atividades de crédito ao longo do ano, diminuindo o (pcr). Os pequenos produtores e as regiões tipicamente agrícolas seriam desfavorecidas nessa dinâmica.

Essas conclusões coincidem com o esperado pela teoria de custos de transação em crédito rural, reforçando a necessidade das agências bancárias conhecerem melhor esses custos, para a aplicação de técnicas gerenciais que permitam a redução dos mesmos, sob o ângulo da eficiência. Viabilizando o atendimento de regiões e /ou grupo de produtores que estariam excluídos do mercado de crédito, devido aos altos custos decorrentes da ineficiência das agências bancárias.

GUIDETTI \& ARAÚJO (1994) estimaram dois modelos econométricos para os custos bancários de transação nos empréstimos em crédito rural para 9 agências de um banco oficial que atua na região sudeste. Quando analisam o custo de transação por R\$ (real) emprestado em função do valor médio dos contratos $(v m c)$, das aplicações totais em crédito rural $(v t)$, da proporção das aplicações em crédito rural sobre as aplicações totais da agência (pcr) e do número de contratos $(n c)$, esses autores chegam aos seguintes resultados: (a) um aumento de 10,0\% em $(v m c)$ tende a reduzir em cerca de $7,2 \%$ pontos percentuais o custo de transação; (b) um aumento de 10,0 em (pcr) tende a 
reduzir em cerca de 1,0\% o custo de transação; (c) um aumento de 10,0\% em (nc) tende a reduzir o custo de transação em cerca de 4,5\%.

Quando estimam um modelo que relaciona o custo de transação por contrato com as mesmas variáveis independentes acima, os autores encontram os seguintes resultados: (a) um aumento em 10,0\% em ( $v m c)$ tende a reduzir em cerca de 7,4\% o custo bancário de transação; (b) um aumento em 10,0\% em (vt) tende a reduzir o custo de transação em cerca de 5,4\%. GUIDETTI \& ARAÚJO (1994) concluem que existe um pequeno intervalo de variação nos coeficientes de elasticidade para as variáveis $(v m c)$ e $(n c)$.

\section{4 - Alternativas Metodológicas}

A literatura sobre estimativas de custo bancário de transação no crédito rural trata de duas principais alternativas metodológicas. CUEVAS (1988) detalha as vantagens e desvantagens dessas alternativas.

A primeira é a que estima econometricamente a função de custo (cost-function econometric approach). Este método se baseia na relação de dualidade existente entre as funções de custo e de produção. Como não existem, à priori, informaçães precisas quanto a natureza da forma da função de produção, este modelo utiliza a minimização de uma função de custo, para chegar, graças à dualidade, a uma boa aproximação das propriedades da função de produção. 
Este método apresenta como vantagem o fato de ser possível realizar estimativas de parâmetros para avaliar economias de escala (entendidas como a redução do custo total médio quando se aumenta a escala de produção da firma) e de escopo (entendida aqui como a redução do custo de produzir uma unidade de um dado produto decorrente da redução do custo marginal de produzir uma unidade de outro produto). O método também permite a verificação da significância estatística da maioria dos indicadores.

Estas vantagens, no entanto, são contrabalançadas pelo fato de que a estimativa dessa função de custo requerer um número muito elevado de informações de boa qualidade. Isso ocorre por causa do grande número de graus de liberdade que são perdidos na estimação de uma função translogarítmica.

Em geral, a função de custo é a seguinte:

$$
C=f\left(Q_{1}, \ldots, Q_{n}, P_{1}, \ldots, P_{n}, \hat{a}\right), \text { onde: }
$$

$C$ é o custo dos recursos envolvidos na intermediação financeira, $Q_{i}$ é a quantidade oferecida do i-ésimo produto e/ou serviço e $\boldsymbol{P}_{j}$ é o preço do insumo $j$. Já a variável $\hat{a}$ sintetiza as variáveis de controle referentes aos custos de regulação e de inadimplência.

Dois pontos são relevantes na avaliação desta função de custo: a especificação da função e a definição dos produtos. Vários estudos sobre estimativa de custos e tecnologia de transação bancária têm enfrentado dificuldades analíticas em virtude das restrições impostas pela especificação da função de custo. Em geral, são utilizadas funções do tipo Cobb-Douglas ou CES. Desta forma, as economias de escala apresentam 
retornos constantes independentemente do nível de produção. Esta é uma restrição muito forte em se tratando de custos de transação.

Estudos recentes tem feito uso da função translog, que é uma forma mais flexível de especificação da função de custo. Esta função consiste em uma aproximação de segunda ordem de uma função arbitrária de custo e assume a seguinte forma para dois fatores e dois produtos:

$$
\begin{aligned}
& \ln C=A_{0}+A_{1} \ln Q_{1}+A_{2} \ln Q_{2}+B_{1} \ln P_{1}+B_{2} \ln P_{2}+\frac{Y_{11}\left(\ln Q_{1}\right)^{2}}{2}+\frac{Y_{22}\left(\ln Q_{2}\right)^{2}}{2}+ \\
& +Y_{12} \ln Q_{1} \ln Q_{2}+\frac{W_{11}\left(\ln P_{1}\right)^{2}}{2}+\frac{W_{22}\left(\ln P_{2}\right)^{2}}{2}+W_{12} \ln P_{1} \ln P_{2}+N_{11} \ln Q_{1} \ln P_{1}+ \\
& +N_{12} \ln Q_{1} \ln P_{2}+N_{21} \ln Q_{2} \ln P_{1}+N_{22} \ln Q_{2} \ln P_{2}
\end{aligned}
$$

$\mathrm{O}$ uso da função translog apresenta como limitação o fato de não existir o logarítimo de zero, reduzindo o poder analítico quando este fato ocorrer em uma estimativa.

As estimativas de economia de escala podem ser obtidas pela expressão:

$$
E S(\text { Economia de Escala })=\frac{\partial \ln C}{\partial \ln Q_{1}}+\frac{\partial \ln C}{\partial \ln Q_{2}}
$$

Se $E S<1$, as economias de escala existem e os custos cresçem menos que proporcionalmente ao crescimento do produto. Quando $E S=1$, têm-se retornos constantes à escala. E finalmente, quando $E S>1$ têm-se deseconomias de escala.

Pode-se determinar também a economia de escala parcial e o custo marginal de cada um dos produtos, conforme as equações: 
$E S_{i}=\frac{\partial \ln C}{\partial \ln Q_{1}} \mathrm{e}$

$$
M C_{i}=\frac{C_{i}}{Q_{i}}\left(E S_{i}\right) \text {, onde: }
$$

$C_{i}$ é a proporção do custo total atribuída ao produto i.

Quando o custo marginal de produzir uma unidade de um dado produto reduz o custo de produzir uma unidade de outro produto têm-se uma economia de escopo, que também pode ser analisada pela translog.

CUEVAS (1988) destaca que outra questão importante na avaliação da função de custo é a definição dos produtos. Os dois critérios mais usados são o número de empréstimos ou depósitos e o valor dos empréstimos ou depósitos. Freqüentemente, usam-se dados de estoque de empréstimos ou depósitos, pois estes guardam uma boa relação de proporcionalidade com os fluxos correspondentes. Além disso, estimar o estoque é mais fácil que acompanhar o fluxo. Outro procedimento que geralmente ocorre é o de utilizar o valor médio dos empréstimos e/ou dos depósitos, devido à heterogeneidade que os caracteriza.

O segundo método utilizado para avaliar as relações econômicas entre o custo bancário de transação no crédito rural e seus fatores determinantes é o da alocação de custo (cost-allocation method). Utilizam-se questionários em nível de agências para determinar os custos envolvidos na captação, distribuição e recuperação dos empréstimos. Tal exigência faz com que o número de observações, seja limitado, o que reduz a aplicação de testes estatísticos dos parâmetros estimados. 


\section{5 - O Modelo econômico}

Neste estudo, o custo bancário de transação no crédito rural é analisado segundo um modelo econômico que estima as relações entre custo de transação e alguns fatores econômicos relevantes. $\mathrm{O}$ modelo proposto assume que o custo bancário de transação no crédito rural é composto por despesas diretas (despesas de pessoal na agência, despesas com assistência técnica, supervisão e monitoramento no campo, diárias de funcionários, combustível, etc.) e despesas indiretas (despesas com pessoal envolvido com outras atividades, aluguel, água, telefone, repografia, publicidade, segurança, limpeza, etc.). Em outras palavras, o modelo assume que o custo bancário de transação no crédito rural corresponde ao custo operacional das agências que prestam esse serviço.

Assume-se que o custo bancário de transação no crédito rural numa dada agência é influenciado pelos seguintes fatores: (1) tamanho da carteira de crédito rural, expresso pelo volume total aplicado em crédito rural ou número de contratos; (2) grau de especialização da agência em crédito rural, expresso pela relação entre aplicações em crédito rural e aplicações totais da agência; (3) eficácia no uso da tecnologia bancária disponível, expressa pelo valor médio dos contratos de crédito rural; e (4) tempo.

Uma importante restrição que será imposta ao modelo econômico proposto é que a taxa de inadimplência ou o risco de crédito não varia significativamente com o tamanho do tomador. No caso do Brasil existem evidências empíricas para acreditar que na medida em que aumenta o tamanho do tomador também aumenta a inadimplência, 
reduzindo portanto as vantagens que o aumento da escala de operações poderia trazer na redução dos custos de transação. Essa restrição, embora reduza a amplitude da análise dos resultados do modelo proposto se faz necessária em virtude da insuficiência de dados sobre a inadimplência da carteira de crédito rural das instituições analisadas na pesquisa.

O volume total aplicado em crédito rural ou o número de contratos indica as possibilidades da agência explorar as eventuais economias de escala disponíveis. Ou seja, a redução do custo total médio quando se aumenta o tamanho da carteira. A proporção das aplicações em crédito rural sobre as aplicações totais indica a possibilidade da agência alocar melhor seus recursos entre o setor de crédito rural e os demais.

Este fator está relacionado com o grau de especialização da agência em crédito rural. Em princípio, a agência que possuir aplicações diversificadas poderia realocar recursos humanos e materiais entre o crédito rural e outras atividades conforme a demanda por esses serviços. Isto é, a agência poderia explorar melhor as eventuais economias de escopo, que vem a ser a redução do custo de produzir uma unidade de um dado produto decorrente da redução do custo marginal de produzir uma unidade de outro produto. Essa possibilidade é importante devido ao caráter sazonal da demanda por crédito rural.

O valor médio dos contratos representa o grau em que uma dada agência poderá aproveitar o tamanho de sua carteira para reduzir custos. Ou seja, quanto maior o valor 
médio dos contratos de uma agência menos recursos materiais e humanos serão necessários para emprestar certo volume global de recursos em crédito rural.

A variável tempo está relacionada com a possibilidade da ocorrência de mudanças estruturais que venham a afetar o custo de transação no crédito rural. Em geral mudanças na tecnologias de comunicação e de processamento de dados e medidas de regulamentação/desburocratização podem levar a uma redução significativa do custo de transação num curto espaço de tempo.

Diante desses aspectos, o custo bancário de transação no crédito rural (CTCR) pode ser representado por:

$$
\begin{aligned}
& C T=f(T C, E A, V M C, T), \text { onde: } \\
& T C \quad=\text { tamanho da carteira de crédito rural; } \\
& E A \quad=\text { grau de especialização da agência em crédito rural; } \\
& V M C \quad=\text { valor médio dos contratos; } \\
& T \quad=\text { tempo. }
\end{aligned}
$$

Estabelecidas as relações entre os fatores econômicos e o custo bancário de transação nas operações de crédito rural, define-se, a seguir, um modelo econométrico que estima relações e testa as hipóteses sugeridas no modelo econômico. 


\section{6 - O Modelo Estatístico}

Para estimar as relações econômicas entre o custo bancário de transação no crédito rural e alguns de seus fatores econômicos determinantes, foi utilizado um modelo de regressão múltipla, linear nos logarítmos, em que o custo bancário de transação é função do volume das aplicações em crédito rural ou do número de contratos; da relação entre aplicações em crédito rural e aplicações totais da agência; e do valor médio dos contratos.

Foi testada ainda nesse modelo de regressão a possibilidade de mudanças significativas no custo bancário de transação no crédito rural em função do fator tempo. Para esse fim, testou-se, no modelo de regressão uma variável dummy.

O modelo ajustado com observações de bancos públicos tem a seguinte forma geral:

$$
\begin{aligned}
& Y_{1}=f\left(X_{1}, X_{3}, X_{4}, D\right), \mathrm{e} \\
& Y_{2}=f\left(X_{1}, X_{3}, X_{4}, D\right), \mathrm{e}
\end{aligned}
$$

$Y_{l}=$ custo bancário de transação por unidade monetária de empréstimo (R\$/R $\left.\$\right)$

$Y_{2}=$ custo bancário de transação total por contrato $(\mathrm{R} \$)$

$X_{1}=$ aplicação total em crédito rural $(\mathrm{R} \$)$ ou $X_{2}=$ número de contratos

$X_{3}=$ aplicações em crédito rural / aplicações totais da agência ( $\mathrm{R} \$ / \mathrm{R} \$$ )

$X_{4}=$ valor médio dos contratos $(\mathrm{R} \$)$

$D=0$ para 1990 e $D=1$ para 1993 
Nos modelos testados a partir dessa forma geral, são estimados os coeficientes da regressão, os desvios-padrão dos coeficientes da regressão, o coeficiente de determinação e os respectivos erros.

$\mathrm{O}$ teste $\mathrm{t}$ determina a significância estatística dos coeficientes da regressão. $\mathrm{O}$ teste $\mathrm{F}$ testa a significância do coeficiente de correlação múltipla dado pelo grau de correlação entre a variável dependente e o conjunto de variáveis independentes. A hipótese nula a ser testada é que os coeficientes da regressão e os coeficientes de correlação múltipla não são significativamente diferentes de zero.

Após a escolha do modelo estatístico, serão realizados um teste simples com regressões de sub-amostras arbitrariamente selecionadas na amostra original e o Teste de Chow para testar a estabilidade dos modelos. Caso as estimativas não venham a sofrer mudanças significativas, o modelo será então considerado estável, ou seja, sua capacidade de previsão será satisfatória porque expressa de forma coerente/consistente o modelo econômico proposto.

Esperam-se sinais negativos para todas as variáveis independentes, inclusive para $D$. Ou seja, o custo de transação tende a diminuir sempre que aumentar o valor de aplicações no crédito rural $\left(X_{1}\right)$, o número de contratos $\left(X_{2}\right)$, a proporção de aplicações em crédito rural sobre as aplicações totais $\left(X_{3}\right)$ e o valor médio dos contratos $\left(X_{4}\right)$. O custo de transação também deve ser menor em 1993 do que em 1990. 


\section{7 - Dados e Definição das Variáveis}

\section{Procedimento Metodológico}

Os dados básicos deste trabalho foram obtidos junto a 62 agências de 4 bancos representativos do sistema bancário público no Brasil, que operam crédito rural nas regiões Nordeste, Sudeste e Sul do Brasil. Os dados referem-se a dois períodos de tempo distintos: metade das observações são de 1990 e metade de 1993. Todos os dados foram convertidos para R $\$$ (reais) de agosto de 1995, sendo deflacionados pelo Índice Geral de Preços - disponibilidade interna da Fundação Getúlio Vargas (IGP-DI/FGV)

Os dados referentes aos bancos públicos foram obtidos através de formulários específicos devidamente aprovados pelas diretorias de crédito rural dos bancos em questão. O preenchimento dos mesmos ficou a cargo dos funcionários das respectivas agências, sob orientação e supervisão de pesquisadores da ESALQ/USP.

Neste formulário, as despesas das agências com crédito rural foram classificadas em: (a) despesas diretas incluindo $\left(\mathbf{a}_{1}\right)$ despesas com pessoal e $\left(\mathbf{a}_{2}\right)$ outras despesas específicas do crédito rural (contratação de serviços de terceiros para avaliação, fiscalização, assistência técnica, peritagem, etc.), diárias com funcionários, combustíveis, impostos; (b) despesas indiretas incluindo $\left(\mathbf{b}_{1}\right)$ despesas com pessoal envolvido em outras atividades, $\left(\mathbf{b}_{2}\right)$ despesas fixas da agência (aluguel, água e esgoto, luz, imposto predial, manutenção e limpeza, etc.) e ( $\left.\mathbf{b}_{3}\right)$ despesas variáveis da agência (impressos, comunicação, reprografia, publicidade, etc.). 
Algumas agências não declararam os gastos com pessoal ocupado em outras atividades que não fossem crédito rural. Para estimar esses gastos, usou-se a relação entre as aplicações em crédito e as aplicações totais de agência como fator de ponderação. Assumiu-se que os gastos com pessoal ocupado em crédito rural em relação ao pessoal ocupado em outras atividades tem a mesma proporção do volume de aplicações.

Para estimar o valor total das aplicações em crédito rural, número de contratos e o valor médio dos contratos foram utilizados os dados referentes à posição do último mês do período em análise. Ou seja, foram utilizados dados de estoque, já que estes guardam uma relação muito próxima aos dados de fluxo, o que foi comprovado observando-se os dados das agências que apresentavam um bom número de operações mês a mês. Muitas agências não apresentaram dados mensais de contratos realizados, tornando assim mais recomendável a opção pelos dados de estoque.

As despesas indiretas com o crédito rural contemplam duas parcelas: custos com pessoal e outros custos. Essas duas parcelas foram estimadas, tomando-se como base de ponderação a relação entre gastos com pessoal exclusivamente ocupado com crédito rural e gastos totais com pessoal na agência.

\section{Definição das Variáveis}

A variável dependente $Y_{l}$ é definida como o custo de transação em R\$ (reais) por $\mathrm{R} \$ 1,00$ emprestado e é calculada dividindo-se os custos totais da agência com crédito 
rural (despesas diretas e indiretas) pelo valor total das aplicações em crédito rural. A variável dependente $Y_{2}$ é definida como o custo de transação em $\mathrm{R} \$$ (reais) por contrato de crédito rural e é calculada dividindo-se os custos totais da agência em crédito rural pelo número de contratos da carteira (ver APÊNDICE 1).

A variável independente $X_{l}$ é definida como o valor total das aplicações em crédito rural em $\mathrm{R} \$$ (reais) e é obtida diretamente dos formulários. A variável independente $X_{2}$ é definida como o número de contratos realizados pela agência em crédito rural e é também obtida diretamente dos formulários. A variável independente $X_{3}$ é definida como a relação entre aplicações em crédito rural e aplicações totais da agência. A variável $X_{4}$ é definida como o valor médio dos contratos em $\mathrm{R} \$$ (reais) e é calculada dividindo-se a variável $X_{l}$ pela variável $X_{2}$. 


\section{4 - ANÁLISE DOS RESULTADOS}

\section{1 - Análise Qualitativa}

Para realizar uma abordagem qualitativa dos dados referentes aos custos de transação e à tecnologia bancária no crédito rural, nas 62 agências dos 4 bancos em estudo, são analisados os seguintes fatores: custo de transação por unidade de valor emprestado, custo de transação por contrato realizado, tamanho da carteira, eficácia no uso da tecnologia bancária disponível e grau de especialização da agência.

Quanto ao custo de transação por unidade monetária de empréstimo, medido pela relação R\$ (reais) gastos por R\$ 1,00 emprestado, as agências foram classificadas em 5 (cinco) faixas de custo, conforme a Tabela 3.

As agências que se encontram na faixa de custo (1) apresentam um patamar de custo semelhante ao encontrado nos países desenvolvidos e nos países em desenvolvimento com baixas taxas de inflação. Nos países desenvolvidos, com amplo e sofisticado mercado financeiro, os custos de transação variam entre $3 \%$ e $4 \%$. Já nos países em desenvolvimento, com inflação baixa (trigres asiáticos e Chile) esses mesmos custos encontram-se entre $5 \%$ e $10 \%$. 
Tabela 3 - Custo de transação por unidade monetária de empréstimo.

\begin{tabular}{cc}
\hline Faixas de Custo & Número de Agências \\
\hline (1) $0 \%$ a $10 \%$ & 13 \\
(2) $11 \%$ a $30 \%$ & 16 \\
(3) $31 \%$ a $50 \%$ & 17 \\
(4) $51 \%$ a $100 \%$ & 9 \\
(5) $>100 \%$ & 7 \\
\hline
\end{tabular}

Fonte: Dados da Pesquisa

As agências que estão na faixa de custo (2) têm custos de transação comparáveis aos encontrados nos países em desenvolvimento com altas taxas de inflação e nos países de baixa renda. As dificuldades em levantar boas informações sobre os tomadores, os escassos recursos de tecnologia bancária disponíveis e a baixa eficiência da mão-de-obra concorrem para elevar substancialmente os custos de transação nos países de baixa renda. Nos países em desenvolvimento, em que o sistema financeiro convive com altas taxas de inflação, os ganhos obtidos com o imposto inflacionário induzem a baixa eficiência microeconômica dos bancos.

Este fato ficou evidente no Brasil após o lançamento do Plano Real, que derrubou a inflação e deu início ao processo de estabilização da economia. O sistema financeiro está enfrentando, certamente, sua maior crise desde que foi estruturado, no final da década de 60, dando sinais claros que não está capacitado, do ponto de vista da eficiência microeconômica, para operar num cenário de inflação baixa.

As agências que estão atuando na faixa de custo (3), certamente apresentam problemas de ineficiência no aproveitamento das economias de escala e escopo, além 
dos problemas afetos à tecnologia bancária, à amplitude do sistema financeiro e à excessiva regulamentação que rege essa atividade.

As agências que se encontram atuando na faixa de custo (4) apresentam os mesmos problemas das agências da faixa (3), mas provavelmente em grau mais elevado por estarem atuando numa região que se caracteriza por uma estrutura fundiária dominada por minifúndios, reduzindo drasticamente o volume e o valor médio emprestado.

As agências que estão na faixa de custo (5) são inviáveis e devem apresentar sérios problemas de logística. Metade dessas agências pertencem ao Banco 2 (banco de desenvolvimento), que certamente trabalha com uma elevada carga de pessoal técnico e uma implicada estrutura burocrática, atendendo a pequenos produtores, com linhas de crédito subsidiado,

A classificação das agências da amostra estudada em 5 (cinco) faixas de custo de transação por contrato, mostrou uma distribuição semelhante àquela encontrada quando o critério utilizado foi o custo de transação por unidade monetária de empréstimo. Esta nova classificação pode ser observada na Tabela 4 .

Entre as 29 agências classificadas nas faixas (1) e (2) pelo critério de custo de transação por unidade monetária de empréstimo, um total de 25 também estão classificadas nas faixas (1) e (2) pelo critério de custo de transação por contrato de crédito rural. 
Tabela 4 - Custo de transação por contrato de crédito rural.

\begin{tabular}{cc}
\hline Faixas de Custo (1) & Número de Agências \\
\hline$(1)<\mathrm{R} \$ 1.000,00$ & 10 \\
(2) $\mathrm{R} \$ 1.001,00$ a $\mathrm{R} \$ 3.000,00$ & 32 \\
$(3) \mathrm{R} \$ 3.001,00$ a $\mathrm{R} \$ 5.000,00$ & 11 \\
(4) $\mathrm{R} \$ 5.001$ a $\mathrm{R} \$ 10.000,00$ & 6 \\
$(5)>\mathrm{R} \$ 10.000,00$ & 3 \\
\hline
\end{tabular}

Fonte: Dados da Pesquisa

Os valores estão em R\$(reais) de Agosto de 1995.

Entretanto, existem alguns casos em que o custo por unidade de valor emprestado é muito baixo e o custo por contrato é bastante elevado. Esses casos ocorreram em agências nas quais é bastante elevada a participação de contratos de investimentos no total de empréstimos da agência. Certamente, essa característica exige uma avaliação individualizada e criteriosa dos projetos a serem financiados, devido ao alto valor envolvido em cada operação. Essas agências devem contar também com pessoal técnico especializado.

Sendo assim, pode-se concluir que a avaliação da eficiência das agências em relação aos custos de transação no crédito rural colherá melhores resultados quando os dois critérios forem usados simultaneamente.

O tamanho da carteira de crédito rural permite fazer algumas inferências sobre a influência da escala de operações no custo de transação dos bancos. Para tanto usaram-se duas medidas: o volume total de recursos aplicados em crédito rural e o número de contratos de crédito rural em cada agência. As agências foram então classificadas em 5 (cinco) faixas de tamanho, conforme a Tabela 5. 
Tabela 5 - Medidas de tamanho da carteira de crédito rural.

\begin{tabular}{|c|c|c|c|}
\hline $\begin{array}{l}\text { Volume Total Aplicado em } \\
\text { Crédito Rural (1) }\end{array}$ & $\begin{array}{l}\text { Número de } \\
\text { Agências }\end{array}$ & $\begin{array}{l}\text { Número de } \\
\text { Contratos }\end{array}$ & $\begin{array}{l}\text { Número de } \\
\text { Agências }\end{array}$ \\
\hline$(1)<R \$ 300.000,00$ & 20 & (1) 0 a 50 & 25 \\
\hline (2) $\mathrm{R} \$ 300.001,00$ a $\mathrm{R} \$ 500.000,00$ & 12 & (2) 51 a 100 & 16 \\
\hline (3) $\mathrm{R} \$ 500.001,00$ a $\mathrm{R} \$ 1.000 .000,00$ & 13 & (3) 101 a 500 & 17 \\
\hline (4) $\mathrm{R} \$ 1.000 .001,00$ a $R \$ 3.000 .000,00$ & 13 & (4) 500 a 1000 & 4 \\
\hline$(5)>\mathrm{R} \$ 3.000 .000,00$ & 4 & $(5)>1000$ & 0 \\
\hline
\end{tabular}

Fonte: Dados da Pesquisa

Os valores estão em R\$ (reais) de Agosto de 1995.

Pode-se observar uma grande concentração de agências operando com um tamanho reduzido de carteira. Esse fato indica que, na amostra, as agências trabalham com pequenos volumes emprestados e concentrados em poucos contratos. Sendo assim, existe um bom espaço para redução dos elevados custos de transação através do aumento na escala de operações (tamanho da carteira).

O valor médio dos contratos de crédito rural foi analisado como forma de avaliar o grau de eficácia na utilização da tecnologia bancária disponível. As agências foram igualmente classificadas em 5 (cinco) faixas, conforme a Tabela 6.

Tabela 6 - Eficácia na utilização da tecnologia bancária disponível.

\begin{tabular}{cc}
\hline Valor Médio dos Contratos de Crédito & Número de Agências \\
Rural (1) & \\
\hline$(1)<\mathrm{R} \$ 5.000,00$ & 19 \\
$(2) \mathrm{R} \$ 5.001,00 \mathrm{a} \$ 10.000,00$ & 24 \\
$(3) \mathrm{R} \$ 10.001,00 \mathrm{a} \$ 30.000,00$ & 3 \\
$(4) \mathrm{R} \$ 30.001,00 \mathrm{a} \$ 50.000,00$ & 1 \\
$(5)>\mathrm{R} \$ 50.000,00$ & \\
\hline
\end{tabular}


Pode-se observar na Tabela 6 que também há espaço nessa amostra para uma redução significativa nos custos, na medida em que os bancos procurem operar com um valor médio dos contratos mais alto. Para efeito de comparação a Tabela 7 mostra estimativas de custo de produção de 1 (um) hectare para algumas lavouras anuais, que representam mais de $80 \%$ da demanda de crédito rural no Brasil.

Tabela 7 - Custos de produção de algumas lavouras selecionadas,1995.

\begin{tabular}{ccc}
\hline Lavouras & Produtividade & $\begin{array}{c}\text { Custo Operacional Total } \\
\text { em RS (reais) }\end{array}$ \\
\hline Algodão & $127 @$ @ ha & 967,84 \\
Arroz de Sequeiro & 40 sacos / ha & 422,37 \\
Arroz Irrigado & 84 sacos / ha & 895,92 \\
Feijão & 27 sacos / ha & 545,37 \\
Mandioca & 20 toneladas / ha & 538,95 \\
Milho & 80 sacos / ha & 377,89 \\
Soja & 38 sacos / ha & 317,60 \\
\hline
\end{tabular}

Fonte: IEA-SP

O valor médio dos contratos nas 62 agências é de $\mathrm{R} \$ 11.133,56$. Considerandose os custos operacionais totais apresentados na Tabela 7 é possível concluir que as agências da amostra estão utilizando mal a tecnologia bancária disponível principalmente porque estão financiando projetos muito pequenos.

A Tabela 8 mostra que com o valor médio dos contratos não é possível plantar mais que 35 hectares. Esse limite de área plantada só é possível para a soja. Já no caso do algodão e do arroz irrigado o valor médio emprestado só permite o plantio de 11,5 e 12,4 hectares, respectivamente. 
Tabela 8 - Área de Plantio por Lavoura com o Valor Médio dos Contratos,1995.

\begin{tabular}{cc}
\hline Lavouras & Área Plantada com Valor Médio dos Contratos \\
\hline Algodão & $11,5 \mathrm{ha}$ \\
Amendoim & $14,5 \mathrm{ha}$ \\
Arroz de Sequeiro & $26,3 \mathrm{ha}$ \\
Arroz Irrigado & $12,4 \mathrm{ha}$ \\
Feijão & $20,3 \mathrm{ha}$ \\
Mandioca & $20,6 \mathrm{ha}$ \\
Milho & $29,4 \mathrm{ha}$ \\
Soja & $35,0 \mathrm{ha}$ \\
\hline
\end{tabular}

Fonte: IEA-SP.

Finalmente, as agências foram avaliadas quanto ao grau de especialização em crédito rural, tomando-se por base a relação entre as aplicações em crédito rural e as aplicações totais da agência, pois quanto maior for a participação do crédito rural nas aplicações totais mais especializadas e eficientes deveriam ser as agências. Como se observa na Tabela 9, o grau de especialização das agências é relativamente pequeno. A quase totalidade das agências apresenta uma participação das aplicações de crédito rural abaixo de $1 / 3$ das aplicações totais.

Tabela 9 - Relação entre aplicações em crédito rural e aplicações totais da agência.

\begin{tabular}{|c|c|}
\hline Aplicações em Crédito Rural / Aplicações Totais & Número de Agências \\
\hline (1) $<10 \%$ & 34 \\
\hline (2) 11 a $30 \%$ & 16 \\
\hline (3) 31 a $50 \%$ & 5 \\
\hline (4) 51 a $80 \%$ & 3 \\
\hline (5) 81 a $100 \%$ & 4 \\
\hline
\end{tabular}

Fonte: Dados da Pesquisa. 
Com essa reduzida participação de crédito rural nos créditos totais das agências poder-se-ia esperar um custo também reduzido com a mão-de-obra encarregada dessa carteira nas agências, mas não é isso o que acontece.

Devido à necessidade de manutenção de pessoal permanentemente envolvido com o acompanhamento da correta execução financeira dos projetos financiados (técnicos agrícolas, fiscais de campo, motoristas, engenheiros agrônomos, veterinários, etc.) os custos com pessoal ligado ao crédito rural são demasiadamente altos.

Outro fator que acarreta um custo elevado com pessoal é o caráter eminentemente sazonal das operações com crédito rural, ou seja, os profissionais especializados em crédito rural ficam a maior parte do ano praticamente ociosos. A demanda por seus serviços está concentrada em três ou quatro meses. Caracteriza-se, nesse caso, uma boa oportunidade para realizar a terceirização desse serviço.

A Tabela 10 mostra a participação dos gastos com pessoal ligado às operações de crédito rural nos gastos totais dos 4 bancos públicos em estudo, que incluem além dos gastos com o restante do pessoal os gastos administrativos (aluguel, impostos, telefone, limpeza, segurança, etc.).

Tabela 10 - Gastos com pessoal ocupado em crédito rural.

\begin{tabular}{cc}
\hline Bancos & Gastos com Pessoal em Crédito Rural / Gastos Totais das Agências \\
\hline Banco 1 & $51,34 \%$ \\
Banco 2 & $60,45 \%$ \\
Banco 3 & $45,88 \%$ \\
Banco 4 & $50,29 \%$ \\
\hline
\end{tabular}

Fonte: Dados da Pesquisa 
Pode-se concluir que as agências em estudo em média emprestam, com um pequeno grau de especialização, pequenos volumes, a pequenos projetos e para um número reduzido de tomadores. Com esse conjunto de características, os custos de transação só poderiam ser elevados, mas a análise qualitativa também permite inferir que existe bastante espaço para redução dos mesmos na medida em que os bancos utilizarem melhor as economias de escala e escopo. Vale lembrar, porém, que o modelo econômico aqui proposto assume que a taxa de inadimplência é constante, independentemente do porte do tomador de crédito.

Os dados da pesquisa também revelam diferenças marcantes em relação aos 4 bancos em estudo. A Tabela 11 mostra os valores médios dos fatores abordados na análise qualitativa para cada um dos bancos em particular.

Tabela 11 - Fatores de eficiência nos 4 bancos estudados.

\begin{tabular}{lcccc}
\hline \multicolumn{1}{c}{ Banco } & $\mathbf{1}$ & $\mathbf{2}$ & $\mathbf{3}$ & $\mathbf{4}$ \\
\hline Número de Agências & 10 & 6 & 8 & 38 \\
$\begin{array}{l}\text { Custo de Transação por Unidade } \\
\text { de Valor Emprestado }\end{array}$ & $76,35 \%$ & $145,04 \%$ & $20,58 \%$ & $32,88 \%$ \\
Custo de Transação por Contrato & $\mathrm{R} \$ 3.731,68$ & $\mathrm{R} \$ 13.508,77$ & $\mathrm{R} \$ 2.284,82$ & $\mathrm{R} \$ 2.657,19$ \\
Volume Total Aplicado & $\mathrm{R} \$ 1.222 .193,72$ & $\mathrm{R} \$ 1.736 .011,94$ & $\mathrm{R} \$ 345.521,15$ & $\mathrm{R} \$ 777.094,95$ \\
Número de Contratos & 130 & 311 & 85 & 93 \\
$\begin{array}{l}\text { Valor Médio dos Contratos } \\
\text { Aplicações em Crédito Rural / }\end{array}$ & $\mathrm{R} \$ 11.530,20$ & $\mathrm{R} \$ 8.947,50$ & $\mathrm{R} \$ 15.522,60$ & $\mathrm{R} \$ 10.450,39$ \\
Aplicaçóes Totais & $30,92 \%$ & $42,18 \%$ & $6,53 \%$ & $16,31 \%$ \\
\hline
\end{tabular}

Fonte: Dados da Pesquisa 
O Banco 1 é um banco comercial que atua na região Nordeste. Esse banco apresenta o segundo maior custo de transação por qualquer dos dois critérios de avaliação. O Banco 2 também atua na região Nordeste. Os custos de transação são elevadíssimos, sendo os mais altos por qualquer dos dois critérios estudados. O baixo valor médio dos contratos deve influenciar negativamente esses custos.

O Banco 3 é um banco comercial que atua na região Sul. Esse banco apresenta o menor custo de transação por unidade de valor emprestado. Embora trabalhe com um reduzido tamanho de carteira por agência, esse banco apresenta o maior valor médio dos contratos, fato que ajuda a reduzir os custos de transação. Outro destaque é que esse banco tem a menor participação de gastos com pessoal ligado ao crédito rural em relação aos gastos totais da agência. Também é reduzida a parcela de aplicações em crédito rural em relação às aplicações totais nas agências.

O Banco 4 é um banco comercial que atua na região Sudeste. Esse banco apresenta custos de transação elevados medidos por qualquer dos critérios. Seu reduzido tamanho de carteira e a pequena participação do crédito rural nas aplicações totais das agências não justificam os elevados gastos com pessoal especializado em crédito rural mantido pelo banco. 


\section{2 - Análise Econométrica}

Realizou-se uma análise cross-section para dois modelos econométricos de regressão múltipla, linear nos logarítmos, com duas variantes cada, para as relações econômicas entre os custos de transação bancária no crédito rural e alguns de seus possíveis fatores determinantes. O primeiro modelo mede os custos de transação por unidade monetária de empréstimo e o segundo modelo mede o custo de transação por contrato. O programa estatístico utilizado foi o Time Series Program (TSP), versão 7.0.

Além da estimativa dos coeficientes das variáveis na forma logarítimica, realizou-se o Teste de Heteroscedasticidade de White (WHITE, 1980). Esse é um teste F que consiste em testar a hipótese nula de que os erros do modelo são homocedásticos, independentes das variáveis incluídas e que a especificação do modelo está correta. Os resultados não permitem rejeitar essa hipótese nula. (ver APÊNDICE 3).

As variáveis $X_{1}$ e $X_{2}$ representam o tamanho da carteira, logo os resultados dos modelos não deveriam diferir economicamente quando usamos uma ou outra variável para ajustá-los. Do ponto de vista estatístico, quando usamos as duas variáveis numa mesma regressão, observa-se uma forte correlação entre ambas. Por essa razão os modelos são ajustados com apenas uma das duas variáveis para o tamanho da carteira.

Quando usamos $X_{1}$, os modelos são identificados como 1a e 2a, já quando usamos $X_{2}$, identifica-se os modelos como $\mathbf{1 b}$ e $\mathbf{2 b}$. Por simplicidade apresentam-se nas 
Tabelas 12 e 13 apenas os resultados das estimativas realizadas para os modelos $\mathbf{1 a}$ e $\mathbf{2 b}$ (ver APÊNDICE 2).

Tabela 12 - Coeficientes de regressão e estatísticas do modelo 1a para estimar as relações entre custo bancário de transação por unidade monetária de empréstimo $\left(Y_{l}\right)$ e fatores determinantes.

\begin{tabular}{lcc}
\hline \multicolumn{1}{c}{ Variável } & $\begin{array}{c}\text { Coeficientes da } \\
\text { Regressão }\end{array}$ & "t" \\
\hline Intercepto & 4,891 & - \\
Volume Total Aplicado em Crédito Rural $(X I)$ & $-0,282^{*}$ & 2,024 \\
Volume Aplicado em Crédito Rural / Aplicaçóes Totais da Agência $(X 3)$ & $-0,146$ & 1,462 \\
Valor Médio dos Contratos $(X 4)$ & $-0,283^{*}$ & 1,916 \\
Dummy $(D)$ & $-0,604^{*}$ & 2,596 \\
$\mathrm{R}^{2}=\mathbf{0 , 3 9 3 7}$ & & \\
\hline *Significativo a 10\% & & \\
\hline
\end{tabular}

As variáveis incluídas no Modelo 1a podem explicar 39,3\% das variações observadas no custo de transação por unidade monetária de empréstimo. Considerandose que os dados são de um cross-section, esse resultado, embora baixo, é satisfatório.

As estimativas dos coeficientes das variáveis do modelo foram testadas quanto ao nível de significância. As variáveis $X_{1}, X_{4}$ e dummy mostraram-se significativas ao nível de $10 \%$. Já a variável $X 3$ não foi significativa a $10 \%$, revelando uma pequena influência do grau de especialização das agências, pelo menos para a amostra analisada.

Essas estimativas sugerem que coeteris paribus: (a) um aumento de $10 \%$ no volume de aplicações totais em crédito rural tende a reduzir em $2,82 \%$ o custo de transação por unidade monetária de empréstimos; (b) um aumento de $10 \%$ no valor 
médio dos contratos tende a reduzir em $2,83 \%$ o custo de transação. O sinal negativo do coeficiente da variável dummy $D$ e seu valor de "t" sugerem que houve uma alteração estrutural reduzindo o custo de transação entre os anos 1990 e 1993.

Tabela 13 - Coeficientes de regressão e estatísticas do modelo $\mathbf{2 b}$ para estimar as relações entre custo bancário de transação por contrato $\left(Y_{2}\right)$ e fatores determinantes.

\begin{tabular}{lcc}
\hline \multicolumn{1}{c}{ Variável } & $\begin{array}{c}\text { Coeficientes da } \\
\text { Regressão }\end{array}$ & "t" \\
\hline Intercepto & 4,902 & - \\
Número de contratos $(X 2)$ & $-0,284^{*}$ & 2,036 \\
Volume Aplicado em Crédito Rural / Aplicações Totais da Agência $(X 3)$ & $-0,146$ & 1,460 \\
Valor Médio dos Contratos $(X 4)$ & $0,434^{*}$ & 3,076 \\
Dummy $(D)$ & $-0,603^{*}$ & 2,592 \\
$\mathrm{R}^{2}=0,3959$ & & \\
\hline * Significativo a 10\% & & \\
\hline
\end{tabular}

As variáveis incluídas no Modelo $2 \mathbf{b}$ podem explicar 39,6\% das variações observadas no custo de transação por contrato $\left(Y_{2}\right)$. Esse resultado revela neste caso que o poder de explicação do modelo independe da forma escolhida para medir o custo de transação.

As estimativas dos coeficientes das variáveis $X_{2}, X_{4}$ e da dummy $D$ mostraram-se significativas ao nivel de $10 \%$. A variável $X_{3}$ foi significativa apenas a $15 \%$.

Essas estimativas sugerem que coeteris paribus: (a) um aumento de $10 \%$ no número de contratos tende a diminuir em $2,84 \%$ o custo de transação; (b) um aumento de $10 \%$ no valor médio dos contratos tende a aumentar em $4,34 \%$ o custo de transação. 
O sinal negativo do coeficiente da variável dummy $D$ e seu valor de "t" sugerem que houve uma alteração estrutural reduzindo o custo de transação entre os anos 1990 e 1993.

O resultado encontrado para a variável $X_{4}$ diverge do esperado pelo modelo econômico proposto. Esse resultado coincide com a observação realizada na análise qualitativa das agências, quando encontramos algumas agências que operam com custos de transação por unidade monetária de empréstimo baixo e custo de transação por contrato alto. A explicação para esse resultado pode estar no fato de que essas agências apresentam uma grande participação de contratos de crédito para investimentos na carteira de crédito rural.

Em geral, os contratos de crédito para investimentos apresentam particularidades que impedem ganhos de escala na sua avaliação. Quanto maior o valor médio dos contratos, maior deverá ser o rigor e detalhamento na avaliação, o que certamente eleva o custo por contrato, mas não necessariamente o custo por unidade monetária de empréstimo, já que os valores liberados em geral são elevados.

Tome-se por exemplo o financiamento de uma plantation de cana-de-açúcar. Um número elevado de variáveis deve ser avaliado (tecnologia, localização, concorrência, mercados de produtos e insumos, impactos ambientais, etc.) para concluir sobre a viabilidade técnica e financeira do empreendimento. Certamente, essa avaliação resultará num custo por contrato elevado, mas se o volume de recursos para a implantação da 
plantation for alto, o custo por unidade monetária de empréstimo poderá ser muito baixo.

Entretanto para agências em que a carteira agrícola é bem distribuída, com participação expressiva de créditos para custeio e comercialização, os resultados em ambos os modelos sugerem que de fato quanto maior o valor médio dos contratos menor será o custo bancário de transação.

Pode-se considerar que o tamanho da carteira de crédito rural e o valor médio dos contratos são os fatores que mais fortemente influenciam os custos de transação bancária no crédito rural para os bancos em estudo. $O$ grau de especialização da agência em operações de crédito rural também influencia os custos de transação, mas sua importância é bem menor.

Esses resultados confirmam as inferências obtidas com a observação qualitativa dos dados, de que a reduzida escala de operações parece ser a principal fonte de ineficiência dos bancos analisados.

\section{3 - Análise de Estabilidade do Modelo}

Para testar a estabilidade do modelo proposto foram utilizados dois métodos distintos. O primeiro método é constituido de vários ajustamentos com conjuntos diferentes de dados da amostra total, arbitrariamente selecionados. O segundo método foi o já consagrado Teste de Chow. 
Para realizar o primeiro teste, os 2 modelos foram ajustados retirando-se da amostra completa, as cinco agências que apresentavam os custos mais elevados, depois as cinco agências com custos mais baixos e finalmente foram retiradas simultaneamente essas 10 agências. Os resultados das regressões realizadas apresentaram uma semelhança grande quando comparados aos obtidos com os da amostra completa. Foram mantidos os sinais dos coeficientes das variáveis e o coeficiente de determinação até melhorou em alguns casos (ver APÊNDICE 4).

O Teste de Chow consiste em verificar a plausibilidade da estabilidade conjunta das variáveis do modelo. Para tanto, a amostra original é dividida em duas sub-amostras e são realizadas regressões para cada uma delas. Em seguida, comparam-se os resíduos obtidos na regressão da amostra completa com os resíduos das regressões das subamostras. Se for mantida a compatibilidade entre resíduos a estabilidade do modelo é aceita.

As agências da amostra original foram misturadas e criaram-se 4 conjuntos de sub-amostras. O primeiro conjunto tem uma sub-amostra de 15 agências, o segundo conjunto tem 20 agências na primeira sub-amostra, o terceiro conjunto tem 25 agências na primeira sub-amostra e finalmente, a primeira sub-amostra do quarto conjunto tem 30 agências. Os resultados obtidos para o Teste de Chow para os 4 conjuntos de subamostras são apresentados na Tabela 14. 
Tabela 14 - Probabilidades associadas ao Teste de Chow.

\begin{tabular}{ccccc}
\hline \multicolumn{5}{c}{ Modelos } \\
\hline Break-Points & $\mathbf{1 a}$ & $\mathbf{1 b}$ & $\mathbf{2 a}$ & $\mathbf{2 b}$ \\
F-Statistic (15) & 0.021 & 0.022 & 0.021 & 0.022 \\
F-Statistic (20) & 0.059 & 0.060 & 0.059 & 0.060 \\
F-Statistic (30) & 0.101 & 0.096 & 0.101 & 0.096 \\
\hline
\end{tabular}

Fonte: Dados da Pesquisa

Todas as probabilidades encontradas foram abaixo de $10 \%$, com exceção dos modelos $1 \mathrm{~b}$ e $2 \mathrm{~b}$, quando a primeira sub-amostra é de 30 agências. Sendo assim o Teste de Chow permite afirmar que analisando as variáveis em conjunto, o modelo apresenta estabilidade.

Esses dois testes permitem afirmar, com certa segurança, que as relações entre os custos bancários de transação no crédito rural e alguns de seus fatores determinantes propostos no modelo econômico são relativamente estáveis, independentemente da amostra de dados que se utiliza para o ajustamento do modelo econométrico. 


\section{5 - CONCLUSÕES}

A estabilização da economia brasileira, após vários anos de convívio com taxas inflacionárias elevadíssimas promoverá uma série de transformações no sistema financeiro e em todos os setores produtivos no Brasil.

A agricultura brasileira pagou caro pelo longo período de desequilíbrio macreconômico. A queda expressiva no volume de recursos financeiros carreados para o setor é um bom indicativo das dificuldades que o crédito rural enfrentou no passado recente. A crise fiscal reduziu drasticamente a capacidade de poupança do governo e impôs a necessidade de buscar financiamento junto ao setor privado nacional.

A poupança doméstica foi então direcionada para financiar o déficit público, em detrimento do financiamento das atividades produtivas, em particular da agricultura, que é uma atividade cercada de riscos e que conta com um ciclo produtivo mais longo.

Paralelamente à redução do volume de recursos para o financiamento rural, os desvios e equívocos observados na operacionalização do crédito rural subsidiado, ao longo da década de 70 , promoveram uma excessiva burocratização/regulamentação das operações de crédito rural. 
Uma evidência do distanciamento do sistema financeiro do crédito rural é o fato de que atualmente, pouquíssimos bancos privados possuem carteiras estruturadas de crédito rural. A obrigatoriedade de aplicar os recursos das exigibilidades em crédito rural é que mantem os bancos privados atuando no financiamento agrícola. Entretanto, poucos bancos privados brasileiros têm na agricultura um volume expressivo de suas aplicações e em geral a carteira agrícola é problemática.

Certamente foram a inflação alta e o financiamento da dívida pública que permitiram aos bancos a obtenção de bons lucros durante a década de 80. Mas num cenário de estabilização da economia, onde a inflação está sob controle e o déficit fiscal tornou-se a prioridade a ser enfrentada, os bancos terão que buscar todas as formas possiveis para aumentar sua eficiência e produtividade. A competitividade operacional é a chave da sobrevivência em tempos de estabilidade.

O financiamento das atividades produtivas, transferindo as poupanças interna e externa dos agentes econômicos superávitários para os deficitários que desejarem investir em projetos lucrativos, será novamente a principal razão de ser do sistema financeiro.

Mesmo sendo uma atividade de alto risco, a agricultura representará uma boa oportunidade de investimentos para os bancos, principalmente se for considerado o tamanho e a complexidade do setor agroindustrial brasileiro.

Seria oportuno que os bancos estruturassem carteiras agrícolas e que implantassem um sistema de controle de custos. No período de realização desta pesquisa 
pudemos constatar que os bancos privados não possuem um acompanhamento dos parâmetros de eficiência alocativa nos diversos serviços que prestam, inclusive dos recursos aplicados na carteira de crédito rural.

A avaliação da rentabilidade em nível de agência não é desmembrada por carteira específica. A avaliação é feita por unidade de negócio, que nesse caso é a própria agência. Compara-se a rentabilidade de todas as aplicações realizadas pela agência com seus custos totais de operação. Se uma agência é superavitária no conjunto de suas carteiras, ela continua operando, mas se for recorrentemente deficitária, será fechada.

Com essa metodologia de avaliação da eficiência bancária, pode-se manter operando a carteira de crédito rural numa agência extremanente ineficiente nesse tipo de operação, desde que no conjunto a agência dê lucro. Por outro lado, pode-se fechar uma agência extremamente eficiente nas operações de crédito rural, apenas porque suas demais atividades geram prejuízos superiores aos lucros auferidos com o financiamento rural.

Observou-se que um número expressivo de bancos privados, sobre os quais levantou-se informações qualitativas, agem da mesma forma. Essa metolologia impediu, inclusive, que nesta pesquisa fossem utilizados dados referentes aos custos de transação no crédito rural para os bancos privados, já que é praticamente impossível especificar os custos relacionados apenas ao crédito rural com os dados disponíveis.

Não existe também o menor interesse por parte das superintendências de crédito rural em mostrar o quanto suas carteiras são ineficientes. Esse fato pôde ser 
evidenciado pela resistência oferecida pelos bancos privados em oferecer dados para a realização da pesquisa.

A restruturação do sistema de crédito rural no Brasil passará necessariamente por três fontes alternativas de financiamento: recursos externos, mercados de futuros e derivativos e um fundo permanente de origem fiscal. Nenhuma dessas fontes de recursos pode prescindir de uma atuação eficiente do sistema financeiro.

A utilização de recursos externos estará ligada diretamente ao crédito para investimento, com participação ativa dos bancos públicos, que conforme pode ser constatar neste trabalho apresentam custos de transação elevadíssimos.

Também o financiamento das operações relacionadas com o comércio exterior agrícola contará cada vez com a participação do sistema financeiro, devido a complexidade da engenharia financeira exigida para competir em igualdade de condições no mercado internacional. As incertezas quanto ao nível futuro das taxas de câmbio e de juros, nos mercados externo e doméstico impõe a parceria permanente entre o sistema financeiro e os importadores e exportadores de produtos agrícolas.

Os mercados futuros e de derivativos também serão uma alternativa atraente para a atuação do sistema financeiro junto à agricultura. A importância relativa do Brasil em vários dos principais mercados mundiais de commodities agrícolas garantirá, junto com a estabilização da economia, uma crescente demanda por operações de hegde. 
Finalmente, qualquer que seja a fonte de recursos públicos para o financiamento rural após a reforma fiscal é evidente que o sistema financeiro continuará tendo um papel importante no repasse desses recursos aos produtores rurais.

É ocioso ressaltar que o sistema financeiro brasileiro não se encontra preparado para atender ao grau de especialização e de eficiência nas operações de financiamento rural que a restruturação do modelo de crédito rural no Brasil exigirá.

Não obstante, pode-se dizer que tal reforma não se realizará completamente até que o sistema financeiro possa atender essas exigências. Sendo assim, um ponto importante para o novo modelo de financiamento agrícola é a restruturação das carteiras agrícolas do sistema bancário.

Nesta pesquisa, a análise de 62 agências de 4 bancos oficiais, que operam em 3 macro-regiões, permitiu a visualização de alguns graves problemas referentes aos custos de transação nas operações bancárias do crédito rural no Brasil. Foi também possível selecionar/sugerir algumas medidas que podem reduzir significativamente a ineficiência.

Através da análise qualitativa dos dados pode-se observar que as agências que operam crédito rural emprestam pequenos volumes, para um número reduzido de produtores. A análise estatística permite concluir que aumentando o tamanho da carteira de crédito rural, ou seja, emprestando mais e atingindo um número maior de produtores os custos podem ser reduzidos.

A análise do valor médio dos contratos efetuados pelas agências revela que as áreas financiadas devem ser extremamente pequenas, sugerindo uma baixa capacidade 
para aproveitar os possíveis ganhos de escala de algumas atividades agrícolas. A análise dos dados sugere que os bancos estipulem um valor mínimo para os empréstimos. Porém, essa restrição poderá resultar na diminuição do volume de empréstimo, pois uma determinada região pode ter a maioria dos produtores com demanda de crédito abaixo desse valor mínimo.

Para resolver esse problema poder-se-ia estimular a formação de grupos de tomadores. Além de diminuir o custo de transação, diminuiria o risco de inadimplência, pois as garantias oferecidas poderiam ser conjuntas.

Não foi possível visualizar, nesta pesquisa, se o grau de especialização da agência em crédito rural é um fator de redução de custos de transação, em particular nas agências em que a participação de contratos de crédito para investimentos for elevada.

A terceirização de serviços como assistência técnica, peritagem, fiscalização e análise econômico-financeira pode reduzir sensivelmente os custos de transação, devido ao maior grau de especialização que se atinge e porque se resolve para a agência o problema da sazonalidade da demanda por crédito rural.

Como se sabe, os custos de transação também englobam os custos de captação e de recuperação de capital. Um processo de desburocratização/desregulamentação das operações de crédito rural faz-se necessário para promover uma redução efetiva no custo de transação no crédito rural. A maior liberalização dessa atividade, certamente, vai imprimir maior concorrência no mercado, contribuindo para a redução dos custos contratuais. 
Tendo em vista os altos níveis de custo de transação com que operam os bancos públicos brasileiros e o caráter de urgência que cerca a restruturação de suas carteiras agrícolas, seria muito importante que esses bancos promovessem um estudo detalhado sobre o estado da arte dos custos de transação nessas instituições financeiras. Com base nos resultados, obtidos no maior número possível de agências, essas instituições deveriam implementar um programa de redução dos custos de transação no crédito rural.

A Febraban deveria realizar um estudo semelhante junto aos bancos privados, procurando conhecer melhor suas estruturas de custo de transação nas operações de crédito rural. Essa medida, além de ajudar a reduzir uma grave fonte de ineficiência, poderia detectar bons nichos de mercado para atuação dos bancos privados nos novos tempos da economia brasileira.

Sugerimos uma abordagem ampla, se possível comparando períodos pré e pós Plano Real, usando-se as duas metodologias apresentadas nesta pesquisa. Também poderia ser ampliado o modelo econômico, incluindo além do custo operacional, os custos de captação e de recuperação de capital.

Estudos dessa natureza certamente permitirão aos bancos o melhor conhecimento dos custos de suas transações e, aos formuladores de política agrícola, uma visualização mais aguçada das reais possibilidades de participação da sistema financeiro no novo modelo de financiamento da agricultura brasileira. 


\section{6 - REFERÊNCIAS BIBLIOGRÁFICAS}

ADAMS, D. W. Son los argumentos en favor del crédito agrícola barato validos? In: ADAMS, D. W.; GONZÁLEZ VEGA, C.; VON PISCHKE, J. D. Credito agricola y desarrollo rural: la nueva vision. $1^{\mathrm{a}}$ edição. Ohio, 1987a. p. 87-101.

ADAMS, D. W. El enigma de proyetos de créditos exitosos en mercados financeiros fracasados. In: ADAMS, D. W.; GONZÁLEZ VEGA, C.; VON PISCHKE, J. D. Credito agricola y desarrollo rural: la nueva vision. $1^{\text {a }}$ edição. Ohio, 1987b. p. 4056.

ADAMS, D. W. Transaction costs in decentralized rural financial markets. Ohio, The Ohio State University, 1994. (Occasional Paper Número 2093, revised version).

ADAMS, D. W. \& ROMERO, A. P. Prestamos a grupo de pobres rurales en la Republica Dominicana: uma innovacion detenida. In: ADAMS, D. W.; GONZÁLEZ VEGA, C.; VON PISCHKE, J. D. Credito agricola y desarrollo rural: la nueva vision. $1^{\mathrm{a}}$ edição. Ohio, 1987. p. 319-330.

ADAMS \& NEHMAN, G. L. Borrowing cost and the demand for rural credit. The Journal of Development Studies, 15:165-76; 1979. 
ALMEIDA, A. Mercados informais como fonte alternativa de liquedez para os agricultores. Piracicaba, 1994. 204 p. Diss. (Mestrado) ESALQ-USP, 1994.

ARAÚJO, P. F. C. de \& ALMEIDA, A. Financiamento rural nos mercados informais. In: SEMINÁRIO NACIONAL: AS DIFÍCEIS OPÇÕES DO FINANCIAMENTO RURAL, Belo Horizonte, MG, 1992. Anais. Belo Horizonte, MG, 1992. p. 1-15.

ARAÚJO, U. M. Assimetria de informações no crédito rural: aspectos teóricos e um modelo de classificação do risco dos créditos concedidos às cooperativas agropecuárias. Piracicaba, 1996. 81 p. Diss. (Doutorado) ESALQ-USP, 1996.

BACEN. Crédito Rural e Agroindustrial, Relatório Mensal de Outubro de 1994, Brasília-DF, 1994, 134p.

BACHA, E. L. Latin America's reentry into private financial markets: domestic and international policy issues. Revista Brasileira de Economia. Rio de Janeiro, 48(4), 1994.

BANCO MUNDIAL. A importância das finanças. Relatório sobre o Desenvolvimento Mundial-1989. $1^{\text {a }}$ edição. Rio de Janeiro, Fundação Getúlio Vargas, 1989. cap. 2, p. 27-43.

BANCO DO BRASIL. Equivalência-Produto no Banco do Brasil: uma avaliação preliminar. Brasília, Banco do Brasil, 1993.

BARROS, G. S. C. Política fiscal e agricultura no Brasil. In: AMARAL, C. M., Politica agrícola para os anos 90. São Paulo, FIPE / Ministério da Economia, 1990. cap. 6. (Relatório de Pesquisa). 
BARROS, G. S. C. \& ARAÚJO, P. F. C. A política de crédito rural no Brasil: Perspectivas para os anos 90. Projeto Mobilização de Poupança, Formação de Capital e Mercados Financeiros na Agricultura Brasileira, Piracicaba, CEPEA / FEALQ, 1991a. Relatório de resultados No. 11

BARROS, G. S. C. \& ARAÚJO, P. F. C. Estimativas de custos bancários de transação do crédito rural no Brasil., Projeto Mobilização de Poupança, Formação de Capital e Mercados Financeiros na Agricultura Brasileira, Piracicaba, CEPEA / FEALQ, 1991b. Relatório de resultados No. 07

BRANDÃO, A. S. P. Efeitos de políticas setoriais e macroeconômicas sobre os incentivos agrícolas. In: XXVII CONGRESSO BRASILEIRO DE ECONOMIA E SOCIOLOGIA RURAL. Piracicaba-SP, 1989. Anais; Piracicaba; SOBER; 1989.

CUEVAS, C. E. Transaction Costs of Financial Intermediation in Developing Coutries. Columbus, Ohio State University, Department of Agriculture Economy and Rural Sociology, 1988.

DIAS, G. L. S. Avanços e perspectivas do agrobusiness brasileiro. In: XXXI CONGRESSO BRASILEIRO DE ECONOMIA E SOCIOLOGIA RURAL. Ilhéus-BA,1993. Anais; Ilhéus; SOBER; 1993.

DIAS, G. L. S. \& AMARAL, C. M. Sistema financeiro rural. In: AMARAL, C. M., Política agrícola para os anos 90. São Paulo, FIPE / Ministério da Economia, 1990. (Relatório de Pesquisa ). cap. 5. 
DÚRAN, T. A. \& LOPES, M. R. Os sistemas de crédito rural dos Estados Unidos, da República Federal da Alemanha e da França: Lições para o Brasil. In: SEMINÁRIO NACIONAL: AS DIFÍCEIS OPÇÕES DO FINANCIAMENTO RURAL, Belo Horizonte, MG, 1992. Anais. Belo Horizonte, MG, 1992.

FRY, M. S. Money, interest e the banking. In: Economic Development. Baltimore, Jonhs Hopkins University, 1988. 522 p. The Jonh Hopkins studies in development.

FUNDAP. O formato institucional do sistema monetário e financeiro: um estudo comparado. São Paulo-SP, IESP / FUNDAP, 1991. (Relatório Final).

GONZÁLEZ VEGA, C. Credito agropecuário artificialmente barato: redistribucion al reves. In: ADAMS, D. W.; GONZÁLEZ VEGA, C.; VON PISCHKE, J. D. Credito agricola y desarrollo rural: la nueva vision. $1^{\text {a }}$ edição. Ohio. 1987. p. 125139.

GONZÁLEZ VEGA, C. \& GARITA, M. A. G. Costos de endeudamiento, tasas de interes y distribucion del credito en Costa Rica. In: ADAMS, D. W.; GONZÁLEZ VEGA, C. \& VON PISCHKE, J. D. Credito agricola y desarrollo rural: la nueva vision. $1^{\text {a }}$ edição. Ohio. 1987. p. 154-164.

GRAHAM, D. H. \& FIRESTINE, R. E. Una agenda para la reforma de los mercados financieros rurales en los paises de ingresos bajos. In: ADAMS, D. W.; GONZÁLEZ VEGA, C. \& VON PISCHKE, J. D. Credito agricola y desarrollo rural: la nueva vision. $1^{\text {a }}$ edição. Ohio. 1987. p. 348-360. 
GUIDETTI, J. C. S. \& ARAÚJO, P. F. C. Custos bancários de transação no crédito rural em agências de banco oficial. Piracicaba, 1994.

GURLEY, J. G. \& SHAW, E. S. Money in a theory of finance. Washington, D.C., The Brookings Institution. 1960.

LADMAN, J. R. Costos de transaciones, racionamiento del crédito y estrutura del mercado: el caso de Bolivia. In: ADAMS, D. W.; GONZÁLEZ VEGA, C. \& VON PISCHKE, J. D. Credito agricola y desarrollo rural: la nueva vision. $1^{\mathrm{a}}$ edição. Ohio. 1987. p. 165-182.

MB ASSOCIADOS. O mercado financeiro em um cenário de estabilização da economia brasileira. São Paulo-SP, 1991.

McKINNON, R. I. Money and Capital in Economic Development. Washington, D.C. The Brookings Institution., 1973.

MENDONÇA de BARROS, J. R. O Financiamento da agricultura. In SEMINÁRIO ANUAL DO PENSA. Águas de São Pedro-SP, 1994.

MENDONÇA de BARROS, M. C. \& PESSÔA, A. S. M. Modernização da agricultura e equivalência-produto. Folha de São Paulo, São Paulo-SP, 1993.

MEYER, R. L. \& CUEVAS, C. E. Reducing the transaction costs of financial intermediation: theory and innovations. Columbus, Ohio state University, 1990. Agricultural Finance Program / Departament of Agriculture Economy and Rural Sociology. 
NAKANO, Y. O crédito rural num contexto de modernização da economia brasileira. In: SEMINÁRIO NACIONAL: AS DIFÍCEIS OPÇÕES DO FINANCIAMENTO RURAL, Belo Horizonte, MG, 1992. Anais. Belo Horizonte, MG, 1992.

WHITE, H., A Heteroskedasticity - Consistent Covariance Estimator and a Direct Test for Heteroskedasticity. Econometrica; 48:817-38, 1980. 


\section{APÊNDICE 1 - Dados Referentes às 62 Agências Analisadas na Pesquisa}

\begin{tabular}{|c|c|c|c|c|c|c|c|c|}
\hline Banco & Agência & Y1 & $\mathrm{Y} 2$ & $\mathbf{X 1}$ & $\mathrm{X} 2$ & $\mathbf{X 3}$ & $\mathrm{X4}$ & $\overline{\mathbf{D}}$ \\
\hline 1 & 1 & 0.447 & 1227.9 & 315724.7 & 115 & 0.154 & 2745.4 & 0 \\
\hline 1 & 2 & 0.193 & 4901.1 & 1267145.2 & 50 & 0.008 & 25342.9 & 0 \\
\hline 1 & 3 & 0.089 & 2961.5 & 4786684.2 & 144 & 0.950 & 33240.9 & 0 \\
\hline 1 & 4 & 1.298 & 2212.3 & 674903.0 & 369 & 0.272 & 1704.3 & 0 \\
\hline 1 & 5 & 0.889 & 5191.9 & 578291.5 & 99 & 0.446 & 5841.3 & 0 \\
\hline 1 & 6 & 0.498 & 2333.3 & 989590.2 & 211 & 0.094 & 4690.0 & 0 \\
\hline 1 & 7 & 2.057 & 3215.1 & 87521.3 & 56 & 0.010 & 1562.9 & 0 \\
\hline 1 & 8 & 1.149 & 6619.3 & 374479.7 & 65 & 0.080 & 5761.2 & 0 \\
\hline 1 & 9 & 0.857 & 3940.8 & 464442.7 & 101 & 0.190 & 4598.4 & 0 \\
\hline 1 & 10 & 0.158 & 4713.5 & 2683154.7 & 90 & 0.891 & 29812.8 & 0 \\
\hline Médias & o Banco 1 & 0.764 & 3731.7 & 1222193.7 & 130 & 0.309 & 11530.0 & \\
\hline 2 & 1 & 0.115 & 1794.6 & 3253246.6 & 208 & 0.929 & 15640.6 & 0 \\
\hline 2 & 2 & 0.347 & 2597.0 & 1226258.6 & 164 & 0.522 & 7477.2 & 0 \\
\hline 2 & 3 & 0.101 & 502.9 & 4278336.2 & 859 & 0.953 & 4980.6 & 0 \\
\hline 2 & 4 & 2.091 & 3452.3 & 949424.6 & 575 & 0.080 & 1651.2 & 0 \\
\hline 2 & 5 & 3.048 & 39855.0 & 209186.9 & 16 & 0.039 & 13074.2 & 0 \\
\hline 2 & 6 & 3.000 & 32850.8 & 499618.7 & 46 & 0.008 & 10861.3 & 0 \\
\hline Médias & o Banco 2 & 1.450 & 13508.8 & 1736011.9 & 311 & 0.422 & 8947.5 & \\
\hline 3 & 1 & 0.316 & 436.8 & 56734.4 & 41 & 0.055 & 1383.8 & 0 \\
\hline 3 & 2 & 0.314 & 2912.3 & 259430.5 & 28 & 0.018 & 9265.4 & 0 \\
\hline 3 & 3 & 0.022 & 44.6 & 1069633.9 & 533 & 0.155 & 2006.8 & 0 \\
\hline 3 & 4 & 0.038 & 2109.5 & 946339.8 & 17 & 0.173 & 55667.1 & 0 \\
\hline 3 & 5 & 0.159 & 222.4 & 26541.5 & 19 & 0.016 & 1396.9 & 0 \\
\hline 3 & 6 & 0.259 & 2006.7 & 77619.3 & 10 & 0.054 & 7761.9 & 0 \\
\hline 3 & 7 & 0.323 & 1450.9 & 116845.2 & 26 & 0.027 & 4494.0 & 0 \\
\hline 3 & 8 & 0.216 & 9095.5 & 211024.6 & 5 & 0.024 & 42204.9 & 0 \\
\hline \multicolumn{2}{|c|}{ Médias do Banco 3} & 0.206 & 2284.8 & 345521.2 & 85 & 0.065 & 15522.6 & \\
\hline
\end{tabular}




\begin{tabular}{|c|c|c|c|c|c|c|c|c|}
\hline Banco & Agência & Y1 & Y2 & X1 & $\mathrm{X} 2$ & $\mathbf{X 3}$ & $\mathrm{X4}$ & $\mathbf{D}$ \\
\hline 4 & 1 & 0.823 & 2485.1 & 326161.0 & 108 & 0.083 & 3020.0 & 0 \\
\hline 4 & 2 & 0.447 & 1948.2 & 453084.5 & 104 & 0.121 & 4356.6 & 0 \\
\hline 4 & 3 & 0.383 & 3273.9 & 470245.9 & 55 & 0.143 & 8549.9 & 0 \\
\hline 4 & 4 & 0.783 & 5590.9 & 257006.1 & 36 & 0.042 & 7139.1 & 0 \\
\hline 4 & 5 & 0.633 & 4081.6 & 199885.5 & 31 & 0.025 & 6447.9 & 0 \\
\hline 4 & 6 & 0.311 & 1958.5 & 264750.0 & 42 & 0.783 & 6303.6 & 0 \\
\hline 4 & 7 & 0.398 & 19043.7 & 287181.5 & 6 & 0.074 & 47863.6 & 0 \\
\hline 4 & 8 & 1.180 & 2393.4 & 64917.6 & 32 & 0.067 & 2028.7 & 0 \\
\hline 4 & 9 & 0.096 & 1244.3 & 401401.6 & 31 & 0.070 & 12948.4 & 1 \\
\hline 4 & 10 & 0.314 & 2737.8 & 349055.0 & 40 & 0.005 & 8726.4 & 1 \\
\hline 4 & 11 & 0.285 & 2587.1 & 426107.9 & 47 & 0.084 & 9066.1 & 1 \\
\hline 4 & 12 & 0.067 & 656.5 & 2746680.8 & 280 & 0.162 & 9809.6 & 1 \\
\hline 4 & 13 & 0.517 & 4748.0 & 211292.2 & 23 & 0.179 & 9186.6 & 1 \\
\hline 4 & 14 & 0.167 & 3483.4 & 1314780.9 & 63 & 0.010 & 20869.5 & 1 \\
\hline 4 & 15 & 0.067 & 1301.7 & 852374.0 & 44 & 0.057 & 19372.1 & 1 \\
\hline 4 & 16 & 0.120 & 3347.2 & 1311979.5 & 47 & 0.264 & 27914.5 & 1 \\
\hline 4 & 17 & 0.059 & 1143.9 & 795227.8 & 41 & 0.475 & 19395.8 & 1 \\
\hline 4 & 18 & 0.224 & 1419.1 & 790691.5 & 125 & 0.033 & 6325.5 & 1 \\
\hline 4 & 19 & 0.179 & 816.2 & 681242.2 & 149 & 0.020 & 4572.1 & 1 \\
\hline 4 & 20 & 0.063 & 1406.6 & 2195105.2 & 98 & 0.357 & 22399.0 & 1 \\
\hline 4 & 21 & 0.352 & 3080.9 & 384673.1 & 44 & 0.111 & 8742.6 & 1 \\
\hline 4 & 22 & 0.215 & 1803.5 & 470053.0 & 56 & 0.090 & 8393.8 & 1 \\
\hline 4 & 23 & 0.241 & 1183.8 & 299652.7 & 61 & 0.205 & 4912.3 & 1 \\
\hline 4 & 24 & 0.243 & 1727.9 & 738546.2 & 104 & 0.078 & 7101.4 & 1 \\
\hline 4 & 25 & 0.321 & 1993.3 & 776602.5 & 125 & 0.141 & 6212.8 & 1 \\
\hline 4 & 26 & 0.396 & 2735.3 & 255695.9 & 37 & 0.033 & 6910.7 & 1 \\
\hline 4 & 27 & 0.108 & 1382.6 & 1010108.9 & 79 & 0.084 & 12786.2 & 1 \\
\hline 4 & 28 & 0.044 & 236.6 & 3528392.0 & 649 & 0.508 & 5436.7 & 1 \\
\hline 4 & 29 & 0.184 & 1207.1 & 1098139.9 & 167 & 0.368 & 6575.7 & 1 \\
\hline 4 & 30 & 0.082 & 1328.4 & 1559983.9 & 96 & 0.053 & 16249.8 & 1 \\
\hline 4 & 31 & 0.342 & 1066.3 & 274695.4 & 88 & 0.237 & 3121.5 & 1 \\
\hline 4 & 32 & 0.383 & 8534.7 & 1227357.6 & 55 & 0.021 & 22315.6 & 1 \\
\hline 4 & 33 & 0.128 & 727.9 & 717121.2 & 126 & 0.045 & 5691.4 & 1 \\
\hline 4 & 34 & 0.212 & 1245.5 & 540698.3 & 92 & 0.064 & 5877.2 & 1 \\
\hline 4 & 35 & 0.655 & 1877.7 & 269520.4 & 94 & 0.060 & 2867.2 & 1 \\
\hline 4 & 36 & 0.021 & 235.2 & 1656350.2 & 149 & 0.304 & 11116.4 & 1 \\
\hline 4 & 37 & 0.677 & 858.7 & 102777.7 & 81 & 0.603 & 1268.9 & 1 \\
\hline 4 & 38 & 0.779 & 4081.2 & 220069.1 & 42 & 0.143 & 5239.7 & 1 \\
\hline \multicolumn{2}{|c|}{ Médias do Banco 4} & 0.329 & 2657.2 & 777094.9 & 93 & 0.163 & 10450.4 & \\
\hline \multicolumn{9}{|c|}{ Médias das 62} \\
\hline
\end{tabular}




\section{APÊNDICE 2 - Estimativas das Regressões dos Modelos 1a, 1b, 2a e 2b}

\section{Modelo la}

LS // Dependent Variable is $\mathrm{Y} 1$

Date: 1-19-1996 / Time: 10:59

SMPL range: 1 - 62

Number of observations: 62

\begin{tabular}{|c|c|c|c|c|}
\hline VARIABLE & COEEEICIENT & STD. ERROR & 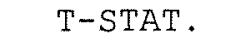 & ट $120+5$ \\
\hline \multicolumn{5}{|c|}{ 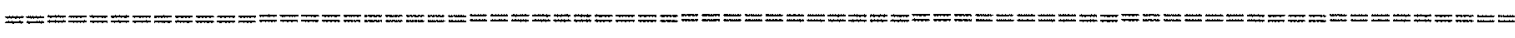 } \\
\hline $\begin{array}{l}\text { C } \\
\times 1 \\
\times 3 \\
\times 4 \\
\text { DUM }\end{array}$ & $\begin{array}{r}4.8911571 \\
-0.2823227 \\
-0.1461769 \\
-0.2828422 \\
-0.6044168\end{array}$ & $\begin{array}{l}1.6966514 \\
0.1394508 \\
0.0999828 \\
0.1476241 \\
0.2328408\end{array}$ & $\begin{array}{r}2.8828298 \\
-2.0245323 \\
-1.4620200 \\
-1.9159619 \\
-2.5958369\end{array}$ & $\begin{array}{l}0.0055 \\
0.0476 \\
0.1492 \\
0.0604 \\
0.0120\end{array}$ \\
\hline \multicolumn{5}{|c|}{ 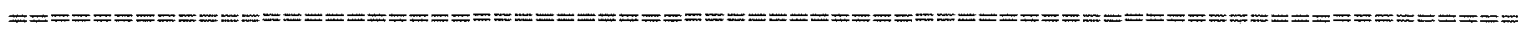 } \\
\hline $\begin{array}{l}\text { R-squared } \\
\text { Adjusted R-squared } \\
\text { S.E. of regression } \\
\text { Log likelihood } \\
\text { Durbin-Watson stat }\end{array}$ & $\begin{array}{r}0.393695 \\
0.351148 \\
0.891133 \\
-78.22141 \\
1.986062\end{array}$ & $\begin{array}{l}\text { Mean of } \\
\text { S.D. of } \\
\text { Sum of } \\
\text { E-stat } \\
\text { Prob }(E\end{array}$ & $\begin{array}{l}\text { ependent var } \\
\text { ependent var } \\
\text { uared resid } \\
\text { ic } \\
\text { atistic) }\end{array}$ & $\begin{array}{r}-1.292035 \\
1.106292 \\
45.26475 \\
9.253035 \\
0.000008\end{array}$ \\
\hline
\end{tabular}

\section{Modelo 1b}

LS // Dependent Variable is Y1

Date: 1-19-1996/Time: 10:58

SMPL range: 1 - 62

Number of observations: 62

\begin{tabular}{|c|c|c|c|c|}
\hline $\begin{array}{l}\text { VARIABLE } \\
=========\end{array}$ & $\begin{array}{l}\text { COEFFICIENT } \\
==========\end{array}$ & $\begin{array}{l}\text { STD. ERROR } \\
\text { Ex= }=======1\end{array}$ & STAT & $\begin{aligned} 2-\text { TAIL } & \text { The } \\
====== & =\end{aligned}$ \\
\hline $\begin{array}{l}\text { C } \\
\times 2 \\
\times 3 \\
\times 4 \\
\text { DUM }\end{array}$ & $\begin{array}{r}4.9052666 \\
-0.2845686 \\
-0.1456013 \\
-0.5656278 \\
-0.6032014\end{array}$ & $\begin{array}{l}1.6949829 \\
0.1395829 \\
0.0999185 \\
0.1412265 \\
0.2327902\end{array}$ & $\begin{array}{l}2 \\
-2 \\
-1 \\
-4 \\
-2\end{array}$ & $\begin{array}{l}0.0054 \\
0.0461 \\
0.1505 \\
0.0002 \\
0.0121\end{array}$ \\
\hline $\begin{array}{l}\text {-squared } \\
\text { djusted R-squared } \\
\text { E. of regression } \\
\text { og likelihood } \\
\text { arbin-Watson stat }\end{array}$ & $\begin{array}{r}0.394266 \\
0.351750 \\
0.890713 \\
-78.19220 \\
1.987180\end{array}$ & $\begin{array}{l}\text { Mean of } \\
\text { S.D. of } \\
\text { Sum of } \\
\text { E-stati } \\
\text { Prob (E- }\end{array}$ & $\begin{array}{l}\text { dependent var } \\
\text { quared resid } \\
\text { tic } \\
\text { tatistic) }\end{array}$ & $\begin{array}{r}-1.292035 \\
1.106292 \\
45.22212 \\
9.275190 \\
0.000008\end{array}$ \\
\hline
\end{tabular}

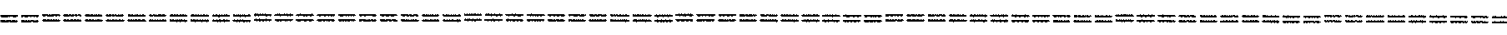




\section{Modelo 2a}

LS // Dependent Variable is Y2

Date: 1-19-1996/Time: 11:01

SMPL range: 1 - 62

Number of observations: 62

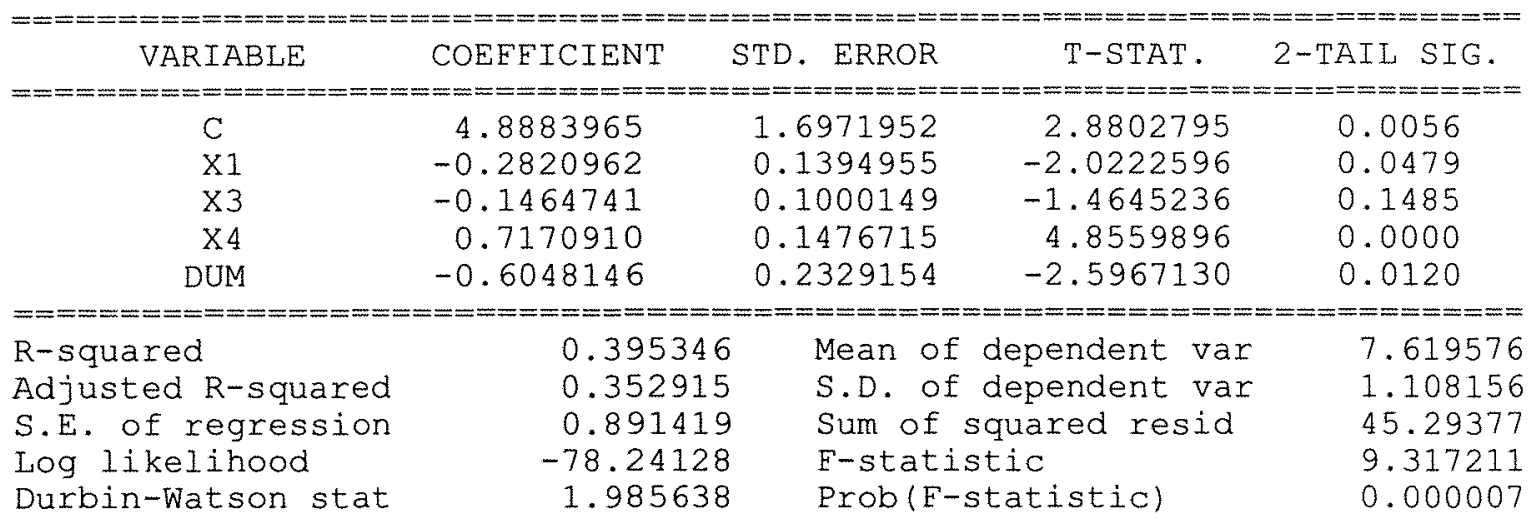

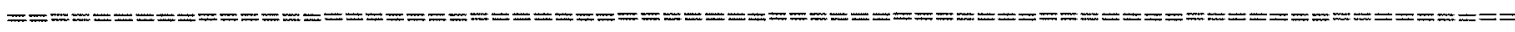

\section{Modelo 2b}

LS // Dependent Variable is Y2

Date: 1-19-1996/Time: 11:00

SMPL range: 1 - 62

Number of observations: 62

\begin{tabular}{|c|c|c|c|c|}
\hline VARIABLE & COEEEICIENT & STD. ERROR & T-STAT. & 2-TAIL SIG. \\
\hline \multicolumn{5}{|c|}{ 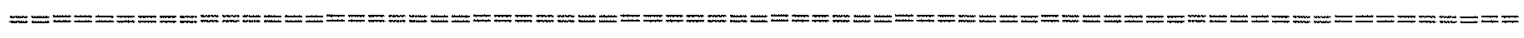 } \\
\hline $\begin{array}{l}\mathrm{C} \\
\mathrm{X} 2 \\
\mathrm{X} 3 \\
\mathrm{X} 4 \\
\text { DUM }\end{array}$ & $\begin{array}{r}4.9025049 \\
-0.2843414 \\
-0.1458987 \\
0.4345319 \\
-0.6035998\end{array}$ & $\begin{array}{l}1.6955275 \\
0.1396278 \\
0.0999506 \\
0.1412718 \\
0.2328650\end{array}$ & $\begin{array}{r}2.8914334 \\
-2.0364245 \\
-1.4597082 \\
3.0758564 \\
-2.5920595\end{array}$ & $\begin{array}{l}0.0054 \\
0.0464 \\
0.1499 \\
0.0032 \\
0.0121\end{array}$ \\
\hline \multicolumn{5}{|c|}{ 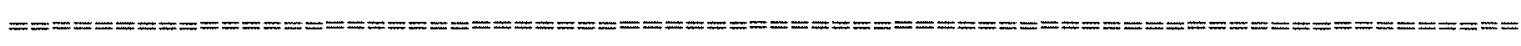 } \\
\hline $\begin{array}{l}\text { R-squared } \\
\text { Adjusted R-squared } \\
\text { S.E. of regression } \\
\text { Log Iikelihood } \\
\text { Durbin-watson stat }\end{array}$ & $\begin{array}{r}0.395915 \\
0.353523 \\
0.891000 \\
-78.21212 \\
1.986756\end{array}$ & $\begin{array}{l}\text { Mean of } \\
\text { S.D. of } \\
\text { Sum of } \\
\text { F-stati } \\
\text { Prob (E- }\end{array}$ & $\begin{array}{l}\text { dependent var } \\
\text { dependent var } \\
\text { quared resid } \\
\text { tic } \\
\text { tatistic) }\end{array}$ & $\begin{array}{l}7.619576 \\
1.108156 \\
45.25118 \\
9.339390 \\
0.000007\end{array}$ \\
\hline
\end{tabular}


APÊNDICE 3 - Teste de Heteroscedasticidade de White

Modelo 1a (sem termos cruzados)

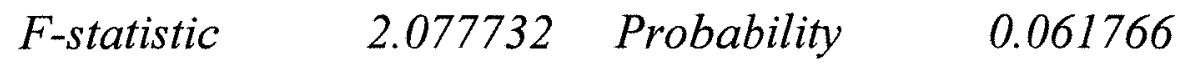

Moldelo 1a (com termos cruzados)

$\begin{array}{llll}\text { F-statistic } & 1.462131 & \text { Probability } & 0.167085\end{array}$

Modelo 1b (sem termos cruzados)

F-statistic $\quad 2.173613 \quad$ Probability 0.051104

Moldelo 1b (com termos cruzados)

$\begin{array}{llll}\text { F-statistic } & 1.464383 & \text { Probability } & 0.166164\end{array}$

Modelo 2a (sem termos cruzados)

F-statistic $\quad 1.956628 \quad$ Probability $\quad 0.078344$

Moldelo 2a (com termos cruzados)

$\begin{array}{llll}\text { F-statistic } & 1.431507 & \text { Probability } & 0.180057\end{array}$

Modelo $2 \mathrm{~b}$ (sem termos cruzados)

$\begin{array}{llll}\text { F-statistic } & 2.108597 & \text { Probability } & 0.058117\end{array}$

Moldelo 2b (com termos cruzados)

$\begin{array}{llll}\text { F-statistic } & 1.440662 & \text { Probability } & 0.176090\end{array}$ 


\section{APÊNDICE 4 - Regressões das Sub-amostras no Teste de Estabilidade do Modelo}

\section{A) Sub-amostra sem as cinco agências com os maiores custos de transação}

\section{Modelo 1a}

LS // Dependent Variable is Y1

Date: 1-22-1996/ Time: 11:13

SMPL range: 1 - 57

Number of observations: 57

\begin{tabular}{|c|c|c|c|c|}
\hline VARIABLE & COEFEICIENT & STD. ERROR & T-STAT. & 2-TAIL SIG. \\
\hline \multicolumn{5}{|c|}{ 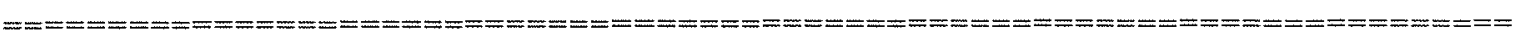 } \\
\hline $\begin{array}{l}\text { C } \\
\times 1 \\
\times 3 \\
\times 4 \\
\text { DUM }\end{array}$ & $\begin{array}{r}5.2695397 \\
-0.4030937 \\
-0.0195215 \\
-0.1462867 \\
-0.3004119\end{array}$ & $\begin{array}{l}1.5257110 \\
0.1312134 \\
0.0951800 \\
0.1459413 \\
0.2155885\end{array}$ & $\begin{array}{r}3.4538256 \\
-3.0720464 \\
-0.2051009 \\
-1.0023664 \\
-1.3934506\end{array}$ & $\begin{array}{l}0.0011 \\
0.0034 \\
0.8383 \\
0.3208 \\
0.1694\end{array}$ \\
\hline \multicolumn{5}{|c|}{ 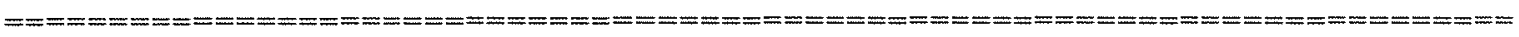 } \\
\hline $\begin{array}{l}\text { R-squared } \\
\text { Adjusted R-squared } \\
\text { S.E. of regression } \\
\text { Log } 1 \text { ikelihood } \\
\text { Durbin-Watson stat }\end{array}$ & $\begin{array}{r}0.370312 \\
0.321874 \\
0.783318 \\
-64.34262 \\
1.297228\end{array}$ & $\begin{array}{l}\text { Mean of } \\
\text { S.D. of } \\
\text { Sum of } \\
\text { E-stati } \\
\text { Prob(E- }\end{array}$ & $\begin{array}{l}\text { ependent var } \\
\text { ependent var } \\
\text { Iared resid } \\
\text { lo } \\
\text { atistic) }\end{array}$ & $\begin{array}{r}-1.474377 \\
0.951224 \\
31.90650 \\
7.645143 \\
0.000064\end{array}$ \\
\hline
\end{tabular}

\section{Modelo 2b}

LS // Dependent Variable is Y2

Date: 1-22-1996 / Time: 11:14

SMPL range: 1 - 57

Number of observations: 57

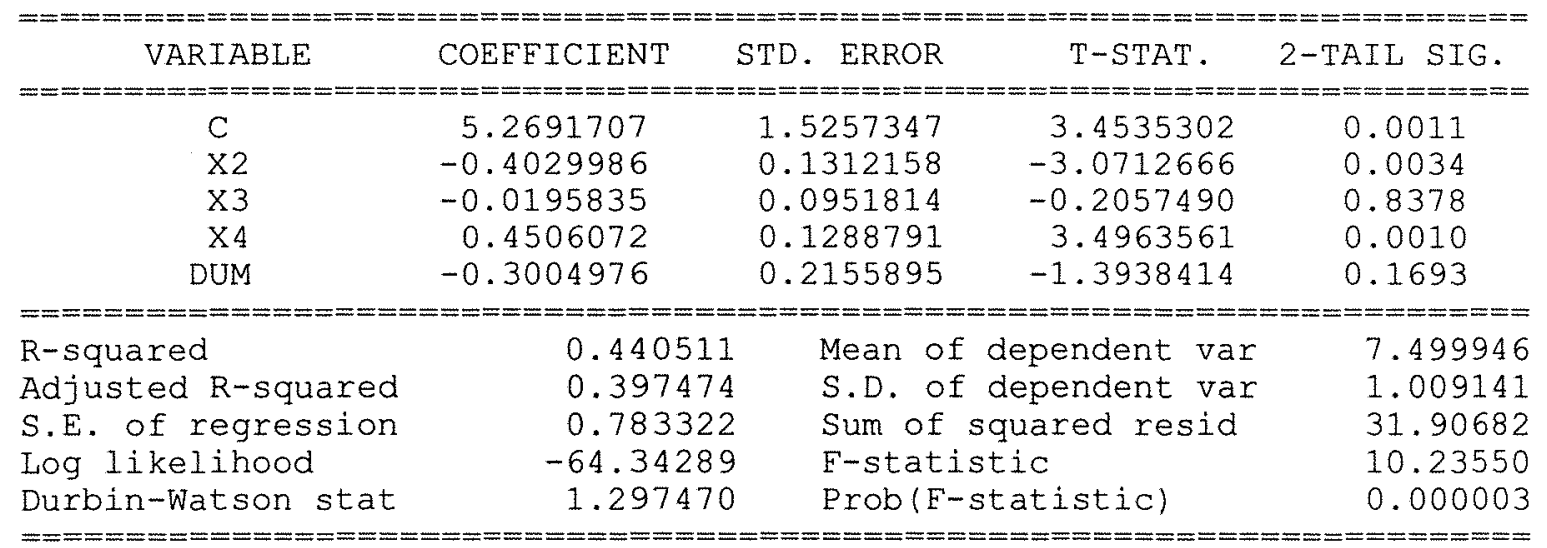


B) Sub-amostra sem as cinco agência com os menores custos de transação

\section{Modelo 1a}

LS // Dependent Variable is Y1

Date: 1-22-1996/ Time: 11:15

SMPL range: 1 - 57

Number of observations: 57

\begin{tabular}{|c|c|c|c|c|}
\hline VARIABLE & COEFEICIENT & STD. ERROR & T-STAT. & 2-TAIL SIG. \\
\hline $\begin{array}{l}\text { C } \\
\times 1 \\
\times 3 \\
\times 4 \\
\text { DUM }\end{array}$ & $\begin{array}{r}4.0269089 \\
-0.1456374 \\
-0.1164340 \\
-0.3604698 \\
-0.6684280\end{array}$ & $\begin{array}{l}1.4378424 \\
0.1250828 \\
0.0864591 \\
0.1392537 \\
0.2031101\end{array}$ & $\begin{array}{r}2.8006609 \\
-1.1643277 \\
-1.3466945 \\
-2.5885838 \\
-3.2909631\end{array}$ & $\begin{array}{l}71 \\
96 \\
39 \\
25 \\
18\end{array}$ \\
\hline $\begin{array}{l}\text { R-squared } \\
\text { Adjusted R-squared } \\
\text { S.E. of regression } \\
\text { Log likelihood } \\
\text { Durbin-Watson stat }\end{array}$ & $\begin{array}{r}0.425084 \\
0.380860 \\
0.744754 \\
-61.46501 \\
1.452126\end{array}$ & $\begin{array}{l}\text { Mean of } \\
\text { S.D. of } \\
\text { Sum of } \\
\text { F-stati } \\
\text { Prob(F- }\end{array}$ & $\begin{array}{l}\text { ependent var } \\
\text { ependent var } \\
\text { uared resid } \\
\text { ic } \\
\text { atistic) }\end{array}$ & $\begin{array}{l}0.946495 \\
28.84225 \\
9.612019 \\
0.000007\end{array}$ \\
\hline
\end{tabular}

\section{Modelo 2b}

LS // Dependent Variable is Y2

Date: 1-22-1996 / Time: 11:15

SMPI range: 1 - 57

Number of observations: 57

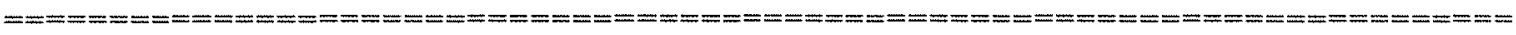
VARIABLE COEFFICIENT STD. ERROR T-STAT. 2-TAIL SIG.

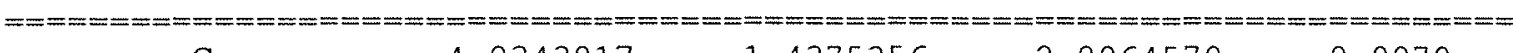

$\begin{array}{lrrrr}\text { C } & 4.0343817 & 1.4375356 & 2.8064570 & 0.0070 \\ \text { X2 } & -0.1471555 & 0.1253617 & -1.1738474 & 0.2458 \\ \text { X3 } & -0.1162632 & 0.0864713 & -1.3445295 & 0.1846 \\ \text { X4 } & 0.4937914 & 0.1224558 & 4.0324047 & 0.0002 \\ \text { DUM } & -0.6679925 & 0.2032097 & -3.2872084 & 0.0018\end{array}$

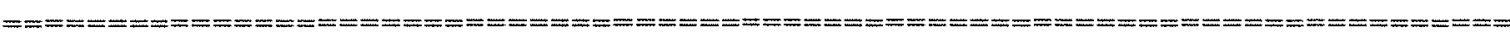

R-squared $\quad 0.415273$ Mean of dependent var 7.771800

Adjusted R-squared $\quad 0.370294$ S.D. of dependent var 0.938742

S.E. of regression $\quad 0.744930$ Sum of squared resid 28.85585

Log likelihood $\quad-61.47845 \quad$ F-statistic $\quad 9.232602$

Durbin-Watson stat $\quad 1.450804 \quad$ Prob(F-statistic) 0.000010

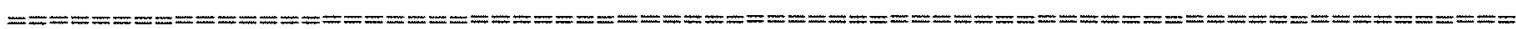


C) Sub-amostras sem dez agências, sendo as cinco com maiores custos de transação e as cinco com menores custo de transação

\section{Modelo 1a}

LS // Dependent Variable is Y1

Date: 1-22-1996/Time: 11:16

SMPL range: 1 - 52

Number of observations: 52

\begin{tabular}{|c|c|c|c|c|}
\hline VARIABLE & COEEFICIENT & STD. ERRO & T-STAT. & -TAIL SIG \\
\hline $\begin{array}{l}\text { C } \\
\text { X1 } \\
\times 3 \\
\text { X4 } \\
\text { DUM }\end{array}$ & $\begin{array}{r}4.4398005 \\
-0.2645257 \\
0.0151445 \\
-0.2282507 \\
-0.3605667\end{array}$ & $\begin{array}{l}1.2085550 \\
0.1133935 \\
0.0778473 \\
0.1338138 \\
0.1773293\end{array}$ & $\begin{array}{r}3.6736437 \\
-2.3328108 \\
0.1945417 \\
-1.7057335 \\
-2.0333165\end{array}$ & $\begin{array}{l}0.0006 \\
0.0240 \\
0.8466 \\
0.0947 \\
0.0477\end{array}$ \\
\hline $\begin{array}{l}\text { R-squared } \\
\text { Adjusted R-squared } \\
\text { S.E. of regression } \\
\text { Log likelihood } \\
\text { Durbin-Watson stat }\end{array}$ & $\begin{array}{r}0.413676 \\
0.363776 \\
0.611640 \\
-45.59250 \\
1.593686\end{array}$ & $\begin{array}{l}\text { Mean of } \\
\text { S.D. of } \\
\text { Sum of } \\
\text { F-stati } \\
\text { Prob(F- }\end{array}$ & $\begin{array}{l}\text { dependent var } \\
\text { dependent var } \\
\text { quared resid } \\
\text { tic } \\
\text { tatistic) }\end{array}$ & $\begin{array}{r}-1.291149 \\
0.766816 \\
17.58286 \\
8.290127 \\
0.000038\end{array}$ \\
\hline
\end{tabular}

\section{Modelo 2b}

LS // Dependent Variable is Y2

Date: 1-22-1996/ Time: 11:16

SMPL range: 1 - 52

Number of observations: 52

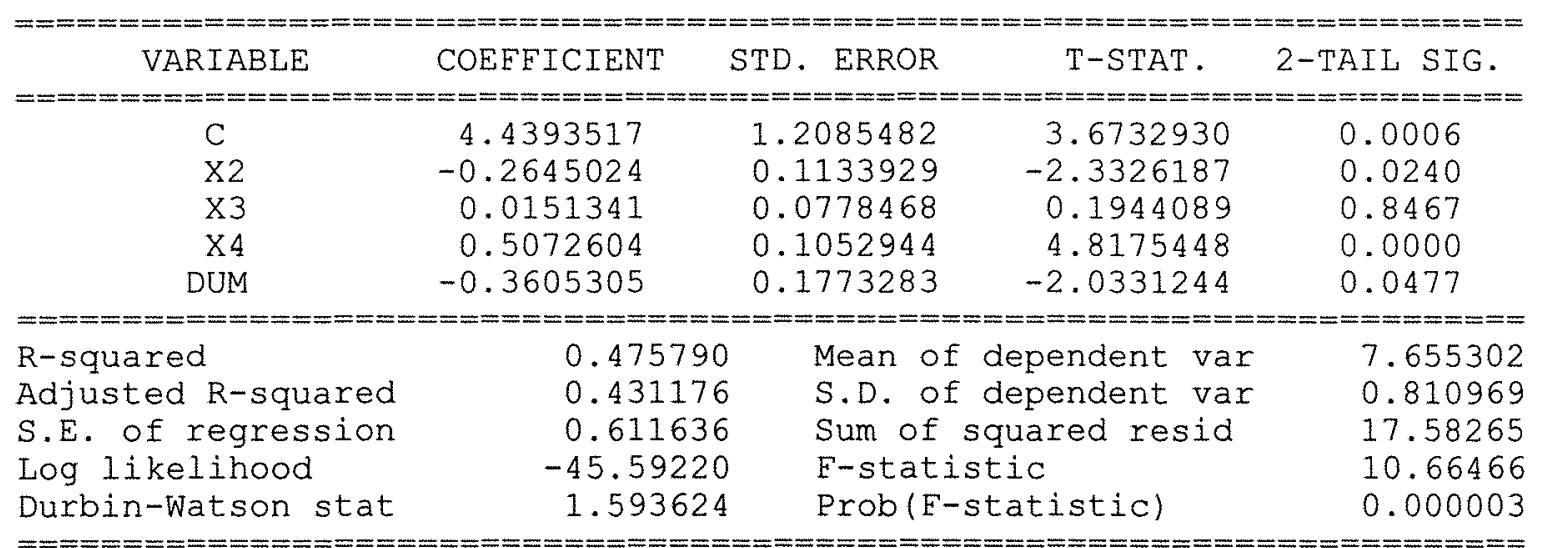

